\title{
Social Vulnerability Indicators for Flooding in Aotearoa New Zealand
}

\author{
Kylie Mason *(D), Kirstin Lindberg, Carolin Haenfling, Allan Schori, Helene Marsters, Deborah Read \\ and Barry Borman
}

check for updates

Citation: Mason, K.; Lindberg, K.; Haenfling, C.; Schori, A.; Marsters, H.; Read, D.; Borman, B. Social Vulnerability Indicators for Flooding in Aotearoa New Zealand. Int. J. Environ. Res. Public Health 2021, 18, 3952. https://doi.org/10.3390/ ijerph18083952

Academic Editors: Kimberley

R. Miner, Shaleen Jain and

Anne Lausier

Received: 1 March 2021

Accepted: 1 April 2021

Published: 9 April 2021

Publisher's Note: MDPI stays neutral with regard to jurisdictional claims in published maps and institutional affiliations.

Copyright: (c) 2021 by the authors. Licensee MDPI, Basel, Switzerland. This article is an open access article distributed under the terms and conditions of the Creative Commons Attribution (CC BY) license (https:/ / creativecommons.org/licenses/by/ $4.0 /)$.
Environmental Health Intelligence New Zealand, College of Health, Massey University, P.O. Box 756, Wellington 6140, New Zealand; k.lindberg@massey.ac.nz (K.L.); c.haenfling@massey.ac.nz (C.H.); A.schori@massey.ac.nz (A.S.); t.h.marsters@massey.ac.nz (H.M.); d.read@massey.ac.nz (D.R.); b.borman@massey.ac.nz (B.B.)

* Correspondence: k.mason@massey.ac.nz

\begin{abstract}
Social vulnerability indicators are a valuable tool for understanding which population groups are more vulnerable to experiencing negative impacts from disasters, and where these groups live, to inform disaster risk management activities. While many approaches have been used to measure social vulnerability to natural hazards, there is no single method or universally agreed approach. This paper proposes a novel approach to developing social vulnerability indicators, using the example of flooding in Aotearoa New Zealand. A conceptual framework was developed to guide selection of the social vulnerability indicators, based on previous frameworks (including the MOVE framework), consideration of climate change, and a holistic view of health and wellbeing. Using this framework, ten dimensions relating to social vulnerability were identified: exposure; children; older adults; health and disability status; money to cope with crises/losses; social connectedness; knowledge, skills and awareness of natural hazards; safe, secure and healthy housing; food and water to cope with shortage; and decision making and participation. For each dimension, key indicators were identified and implemented, mostly using national Census population data. After development, the indicators were assessed by end users using a case study of Porirua City, New Zealand, then implemented for the whole of New Zealand. These indicators will provide useful data about social vulnerability to floods in New Zealand, and these methods could potentially be adapted for other jurisdictions and other natural hazards, including those relating to climate change.
\end{abstract}

Keywords: social vulnerability; resilience; indicators; natural hazards; flooding; disaster; health

\section{Introduction}

Natural hazards can have major impacts on people's health and wellbeing, both in the short and long term, and through both direct and indirect impacts from the hazard. Managing disaster risk, and protecting the health and wellbeing of populations from natural hazards, is becoming increasingly important in this changing world. Climate change is likely to increase the frequency and severity of climate-related disasters such as floods in many regions of the world [1]. Additionally, population growth, urbanisation, and changing socioeconomic conditions can increase society's exposure and vulnerability to natural hazards [2]. In this context, having a clear understanding of the likely impacts of disasters on people's health and wellbeing, and who is the most vulnerable to these impacts, can help support the planning and targeting of interventions [3].

In Aotearoa New Zealand, the most frequent and costly natural disaster is flooding. Approximately two-thirds of the New Zealand population live in flood-prone areas [4], and many of New Zealand's towns and cities are built on floodplains. On average, a major flood occurs every eight months in New Zealand [4], and the total costs of flooding in New Zealand are estimated to be more than $\$ 125$ million per year [5]. In the ten year period 2009-2018, there were 28 flood-related events where insurance damages were more than 
$\$ 1$ million (inflation adjusted) [6]. In New Zealand, floods have had substantial impacts on people's lives, in both the short term (e.g., gastrointestinal illness), as well as longer term (e.g., psychological distress, displacement) [7-10]. Flooding is likely to increase in frequency and severity in New Zealand due to climate change [4], and is one of the key risks from climate change this century in New Zealand [11].

Flooding can have a range of health impacts, including drowning, trauma injuries, hypothermia, and infections, as well as electrical injuries, burns and explosives injuries [12-16]. Floods can also increase the risk of waterborne diseases such as gastrointestinal illnesses, hepatitis A and E, cholera, typhoid fever, leptospirosis, and vector-borne diseases [12,13,15] and can increase the risk of heart attacks and respiratory problems [14], poor pregnancy outcomes [12,17], poor mental health [17], and exacerbations of substance abuse issues [17]. Longer term, flooding can impact on food supply, and lead to food insecurity and poor nutrition [12].

Infrastructure breakdown and disruptions to essential infrastructure and services during and after floods can also have substantial health impacts [17]. Disruptions to transport systems can delay first responders, impact on evacuation, and prevent access to health services, which can affect people with physical and mental health issues [17], including those on opioid substitution treatment [18]. Power outages can lead to food-borne illnesses through lack of refrigeration, carbon monoxide poisoning from unventilated generators, and affect medically dependent people, the young, and the old [15,17]. Floodwaters can also cause property damage, which can lead to overcrowding and displacement, and respiratory issues from damp and mouldy housing $[19,20]$. Flooding can also lead to loss of employment, lack of access to childcare services and schooling, and increased domestic violence [21,22].

The negative impacts of natural hazards such as floods on people's health and wellbeing are not evenly distributed throughout society. People who are already struggling financially, who live in poor-quality housing, or who are socially isolated are more likely to experience significant adverse impacts from natural hazards $[16,23,24]$. Furthermore, not everyone in the population is able bodied, can hear, see and move, can understand the hazard, and can understand and carry out what they need to do to prepare or escape the hazard [25]. As a result, some population groups are more vulnerable to natural hazards and are less able to prepare for, cope with, and recover from natural hazards than others. Nonetheless, if community and government services are equitable and accessible before, during and after a disaster, more vulnerable people can have the same opportunity as others to be resilient [25]. Similarly, fully considering the needs of specific population groups in emergency management planning can reduce their vulnerability to natural hazards $[23,26]$.

The term 'social vulnerability' is broadly used to refer to pre-existing conditions, characteristics or circumstances of people that affect their ability to prepare for, respond to, and recover from natural hazards [27]. A similar concept is 'resilience', which refers to the ability to "anticipate and resist the effects of a disruptive event, minimise adverse impacts, respond effectively post-event, maintain or recover functionality, and adapt in a way that allows for learning and thriving" [28], which can occur at the level of individuals, communities, organizations and / or states [29]. Information on social vulnerability is useful for risk assessment, understanding where the greatest need may be before, during and after a natural hazard, and providing insight about the needs of the local people and the likely impacts that natural hazards may have [25]. Social vulnerability indicators can therefore inform disaster risk reduction, preparedness, mitigation plans, and response and recovery activities, for civil defence practitioners, health authorities, local authorities, emergency services, and community organizations.

Several sets of social vulnerability indicators for natural hazards exist, including the Social Vulnerability Index (SoVI) [27,30], the Social Determinants of Vulnerability Framework [25], and the Social Vulnerability Index for Disaster Management [23] in the United States. Additionally, flood-specific social vulnerability indicator sets include the Urban 
Municipality Flood Vulnerability Index in Brazil [31], the Social Flood Vulnerability Index in England and Wales [32], and the Cologne (Germany) flood indicators [33]. Populations groups identified as being most vulnerable to floods, and/or natural hazards more broadly, include children, older adults, women, people with pre-existing health conditions, people living in poverty, low-income households, low educational attainment, unemployment, single parents, disabled people, certain races or ethnic groups, institutionalised populations, nursing home residents, renters, people with shorter length of residence, housing stock, poor quality housing, non-car ownership, household crowding, living in rural communities, and having English as a second language [7,23,25,27,31-35]. However, despite the numerous pieces of work on indicators of social vulnerability and resilience to floods and natural hazards more broadly, there is no definitive set of social vulnerability indicators or single approach to indicator development [34,36].

There are several challenges in developing social vulnerability indicators for natural hazards. Existing indicator lists and data sources may be difficult to transfer to a different setting (e.g., country to country), as indicator sets need to be context specific and relate to the social environment within that country [3]. Consequently, using 'off the shelf' indicator sets, or simply replicating indicator sets from other countries, may not work well in a country-specific setting. Furthermore, considering only a narrow set of impacts (e.g., only deaths and injuries) when scoping the social vulnerability indicators can miss important aspects such as housing, social connectedness, and economic wellbeing [35]. Additionally, some statistical methods (such as principal components analysis) used to develop indices and/or indicator sets can be influenced by data availability and the weightings used, leading to certain types of indicators (such as economic factors) having greater influence [34]. These statistical methods can also be challenging for policymakers to understand, and problematic to replicate, as the outputs are only pertinent to the time period and geographical area covered by the analysis. While summarising indicators into a single index value can provide simplicity of interpretation, it can also hide the underlying reasons for vulnerability in a local area [34].

In New Zealand, relatively few indicator sets relating to social vulnerability and natural hazards have been developed. Studies have tested the use of an index of neighbourhood socioeconomic deprivation (NZDep) as a proxy for vulnerability to natural hazards [37], proposed a set of earthquake social vulnerability indicators [35], and explored potential vulnerability indices for flooding in the Hutt Valley, New Zealand [34]. However, no set of social vulnerability indicators for natural hazards or flooding has been fully developed and implemented in the New Zealand context. While emergency management organizations well understand the factors that shape social vulnerability to natural hazards, there is little quantitative information at the local level to help inform their emergency management activities.

This study developed a set of social vulnerability indicators for flooding in Aotearoa New Zealand. These indicators aimed to provide a practical tool to inform local efforts in emergency management and health care, before, during and after a flood, and provide information to inform important risk reduction and emergency management activities.

The specific aims of this study were:

1. To identify a set of social vulnerability indicators for flooding for New Zealand

2. To identify populations vulnerable to flooding, and important facilities and infrastructure within flood zones, for a case study of Porirua City, New Zealand

3. To identify how indicators could potentially be used by emergency management, local councils and the health sector.

\section{Existing Vulnerability Frameworks and Indicators}

\subsection{Conceptual Models for Vulnerability}

In natural hazards research, risk is generally conceptualised as the potential for loss, and is given as a function of hazard and vulnerability, where vulnerability refers to the propensity of exposed people to experience harm and suffer loss [33]. Disaster risk has also 
been defined as a function of hazard, exposure, and vulnerability/capacity [38,39], while the Intergovernmental Panel on Climate Change (IPCC) has defined climate change risk as a function of hazard, exposure and vulnerability [40]. Thus, vulnerability is often a core component of disaster risk.

Some models already exist for understanding and describing different aspects of social vulnerability to natural hazards. The Hazards-of-Place model focuses on how the geographic context interacts with the social characteristics of society to produce the overall place vulnerability [30]. The Pressure and Release model describes how vulnerability arises from inequalities in society, which create pressure in society [41]. The Access model focuses on the access that people have to capacities, assets and opportunities [41]. The Vulnerability Framework frames vulnerability as having components of exposure, sensitivity and resilience, and being influenced by a range of contextual factors at the societal and environmental levels [42]. These models are not generally conflicting; rather, they describe vulnerability from different perspectives and have different focuses [33]. However, they generally do not explicitly consider the impacts of climate change.

For climate change vulnerability, the IPCC describes how vulnerability and risk are influenced by the hazard, exposure, sensitivity, and people's capacity to cope and adapt [43]. Similarly, the US Climate Change and Health framework for determinants of vulnerability of human health to climate change includes exposure, susceptibility and adaptive capacity [17].

The Methods for the Improvement of Vulnerability Assessment in Europe (MOVE) framework has been developed as a generic conceptual framework for guiding vulnerability assessment and development of indicators [33]. The MOVE framework takes a holistic approach, being designed to work for not only natural hazards but also climate change. It incorporates the key elements of risk, hazard and vulnerability [33]. According to the MOVE framework, hazards (natural events or socio-natural events) interact with society (which includes vulnerability), to produce a risk (economic, social or environmental potential impact). In the MOVE framework, vulnerability has three components [33]:

i. Exposure: temporal and spatial;

ii. Susceptibility/fragility: the predisposition to suffer harm; can include physical, ecological, social, economic, cultural, and institutional;

iii. Lack of resilience: lack of capacity to anticipate, cope and recover.

The MOVE framework has been tested in a number of case studies, including for flooding in Cologne (Germany) [33], Tokyo (Japan) [44] and Côte d'Ivoire [45].

The MOVE framework can be used to consider different types of vulnerability, including social, physical, ecological, economic, cultural and institutional. The social dimension of vulnerability in the MOVE framework refers to the propensity of people's wellbeing to be damaged [33].

\subsection{Existing Indicators for Social Vulnerability to Flooding}

A range of social vulnerability indicators for natural hazards have been developed internationally. Some indicator sets or indices have been specifically developed for flooding, while others have been developed for natural hazards more generally (see Appendix A for more details).

One of the first social vulnerability indices for natural hazards was the Social Vulnerability Index (SoVI) [27,30]. The SoVI was based on the Hazards-of-Place model of vulnerability, and used statistical methods to reduce 42 variables to a key 11 variables. These variables were then weighted and combined to create the index, at the United States county level. The variables were a mix of demographic characteristics, built environment, and infrastructure characteristics.

In the United States, the Social Determinants of Vulnerability Framework identified key social factors that resulted in people having disproportionate exposure to risk and a decreased ability to avoid or absorb potential losses [25]. A grounded theory approach was carried out, using a link analysis of social factors from existing literature, to investigate the 
relationships between social factors. Seven key interrelated social factors were identified: children, older adults, people with disabilities, chronic and acute medical illness, social isolation, low-to-no income, and people of colour. Additional indicators that were also found to be important included women, lower educational attainment, limited English proficiency, renters, and a lack of a vehicle.

Several sets of social vulnerability indices for floods exist. The Urban Municipality Flood Vulnerability Index identified key components of urban vulnerability to floods in Brazil, incorporating age, health status, education, income, work status, access to telecommunications, housing, flood preparedness, and access to services [31]. The Social Flood Vulnerability Index, developed in the United Kingdom, included indicators about financial deprivation, pre-existing health problems, single parents, and the elderly [32]. The Social Vulnerability Index for Disaster Management created an index for the United States, based on 15 indicators across four social vulnerability domains: socioeconomic status, household composition and disability, minority status and language, and housing and transportation [23].

In the New Zealand context, one study tested the use of the New Zealand Index of Socioeconomic Deprivation (NZDep) [46] to understand vulnerability due to limited financial resources, as a proxy for social vulnerability to natural hazards [37]. However, the study noted that NZDep did not tell the full story of vulnerability, and could not act as a proxy for all types of vulnerability, such as age or disability status. A comparison of potential vulnerability assessment methods for flooding in the Hutt Valley (in the Wellington region of New Zealand) identified 38 initial proxy indicators relating to vulnerability to flooding, in the broad groupings of demographic, social and economic indicators [34]. This study tested different methods for combining indicators into indices, and concluded that different methods gave different picture of vulnerability. They therefore recommended that a comprehensive vulnerability assessment was required to fully understand vulnerability to floods, rather than simply an index. Subsequently, Kwok identified potential social vulnerability indicators for earthquakes in New Zealand, using the SoVI index as a starting point for indicators [35]. The suggested indicators covered poverty, race and ethnicity, wealth, age, gender, and care dependency, medical disability and health care access. The final indicator set was not implemented, as the study did not identify any data sources or indicator definitions, or make an indicator dataset available. The study concluded that social vulnerability indicators need to be context sensitive, and that future indicator development work could consider community objectives, such as knowledge and skills, economic wellbeing, housing, health, safety, social connectedness, civic participation, and population dynamics. Other studies in New Zealand have investigated factors relating to resilience to natural hazards, including describing resilience factors among New Zealand's indigenous people, Māori, after the 2011 Christchurch earthquake [47], developing a national resilience index (incorporating system-level resilience factors) [48], and identifying resilience factors within selected communities, using qualitative research methods [49].

In summary, there is currently no consensus on the specific variables to use when measuring social vulnerability to natural hazards. However, some key socio-demographic groups appeared across multiple indicator sets, including young children, elderly, people with chronic health conditions, people with disabilities, low income, access to transport or communications, housing (rental housing, housing quality, overcrowding), occupation, and race or ethnicity. Many international indicator sets were also context specific, for example including indicators on the presence of informal settlements (e.g., slums and mobile homes), which may not be relevant to all countries. Additionally, a variety of methods have been used to develop indicator sets, with few studies using a conceptual framework to understand the underlying reasons why people might be vulnerable to flooding, or to guide indicator selection. Of those that did, the MOVE framework was the most common, identifying indicator for exposure, susceptibility and lack of resilience [33,45]. Other indicator sets used more generic dimensions, such as demographic, social and economic factors. 
Given the scarcity of information and data about vulnerable populations in New Zealand, our study aimed to fill this gap by developing a set of social vulnerability indicators for flooding in New Zealand. Rather than attempting to replicate indicator sets developed in different jurisdictions and social contexts, which may not have been relevant for New Zealand, we chose to use a concept-driven approach for developing our indicator set. In addition, we chose to develop a set of indicators rather than an index, given the limitations of indices.

\section{Materials and Methods}

This study developed a set of social vulnerability indicators for flooding for New Zealand, then used a case study approach to test the indicators. An established indicator development process was used in the selection, design and implementation of the indicators.

\subsection{Study Area}

New Zealand is a geographically isolated island nation of approximately 5 million people, with many natural hazards, including floods, earthquakes, droughts and volcanoes.

A case study area of Porirua City was used to test the social vulnerability indicators. Porirua City is a territorial authority of approximately 180 square kilometres in size, located approximately 25 kilometres north of the capital city of Wellington, in the lower North Island of New Zealand. Porirua had an estimated population of 56,800 people in 2018.

Porirua has been affected multiple times by flooding, including in 2015 [50] and 2016 [51], which led to road closures, school closures, and flooded properties. In particular, flooding has affected the low-lying neighbourhood of Takapūwāhia, which has a marae for the local Māori iwi, Ngāti Toa Rangatira, that has come close to flooding on multiple occasions. Figure 1 shows the Porirua area with flood zones, with the area units of Cannons Creek, Waitangirua, Elsdon-Takapūwāhia, Porirua East, Ascot Park, Porirua Central, and Titahi Bay particularly affected.

\subsection{Indicator Development Process}

A robust and well-tested process for developing indicators was used. This indicator development process was adapted from methods for developing environmental health indicators [52], based on the World Health Organization's process for developing children's environmental health indicators [53] and Statistics New Zealand guidance for developing indicators [54]. Methods for developing environmental health indicators are relevant for this work, given their focus on the impacts of environmental hazards on human health and wellbeing, and the social, economic and demographic context in which these impacts occur.

The indicator development process followed three major stages: scoping, selection, and design and implementation (Figure 2). Stakeholder engagement was included through the indicator development process to gain the perspective of experts and potential end users, with the Porirua geographical area used as the focus. The stakeholder group comprised representatives from the national emergency management agency, natural hazards researchers, as well as local Porirua representatives from the regional emergency management group, local council, public health service, and local health providers. Using this case study approach and engagement with stakeholders enabled identification of information needs of end users, feedback on the conceptual framework and proposed indicators, and identification of how the indicators would be used and best presented.

\subsubsection{Scoping Stage}

The scoping stage defined the information and data needs for the indicators, through identifying the end users, indicator purposes, and key issues that the indicators needed to cover. For this study, impacts of flooding on human health and wellbeing, and factors that increase people's vulnerability to these impacts, were identified through reviewing background literature and key summary literature, expert opinions, and previous indicator sets. Previous conceptual frameworks for social vulnerability, and social vulnerability 
indicator sets, were also reviewed. This stage also defined the study scope, and the world view and understanding of the issues that the indicators needed to reflect. A public health perspective was used to guide the study, and a strengths-based approach was incorporated where appropriate. The study was limited to individual-level factors influencing social vulnerability, rather than system-level indicators.

Potential end users of the indicators were also identified, including in the fields of emergency management, local and central government, and the health sector. Key needs for end users included having indicator data at the most detailed geographic level possible, to ensure that the vulnerability of local neighbourhoods could be understood. Data needed to be up-to-date, and relevant and meaningful to emergency management activities and the New Zealand context. Data were also needed about both the relative impact of vulnerability in an area, and the actual number of people affected. The policy context was also reviewed to identify how the indicators could be used within the existing emergency management structure in New Zealand.

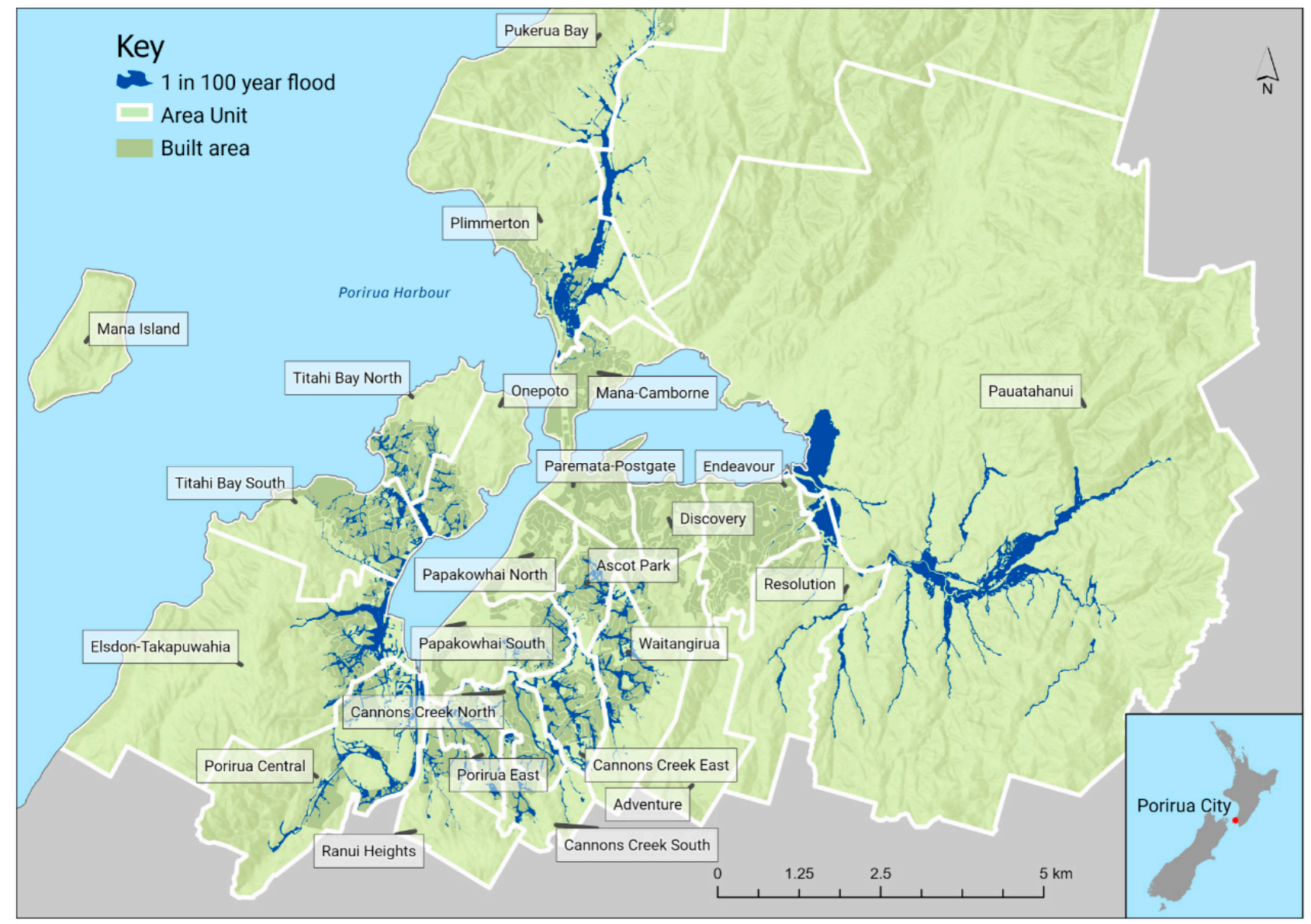

Figure 1. Map of Porirua City, with flood hazard zones and 2013 area unit boundaries. Note: Flood hazard zones give the flood hazard for a 1-in-100 year flood event. These hazard zones account for 100 year climate change impacts, in terms of sea level risk and increased rainfall. The models have used 1 metre sea-level rise and a $20 \%$ increased rainfall. The models were prepared by Wellington Water. Sources: ESRI, NASA, NGA, USGS, OpenStreetMap, Statistics New Zealand, Wellington Water, Porirua City Council. 


\section{SCOPING}

\section{Understand the issue}

- Develop an understanding of the issue (eg through background literature, key summary literature, expert opinions, previous work on indicators)

- Understand the impact the hazard has on people's health and wellbeing

- Understand who is more likely to be affected
Understand key users and their needs

- Identify key users

- Analyse user information needs

- Review existing data and indicators available

- Review policy context

\begin{tabular}{|l|} 
Finalise the information needs that the indicator(s) will meet \\
- Identify rationale for indicator development \\
- Identify the specific purposes and key users of the set of indicators \\
- Identify any information needs of key users (such as spatial scale)
\end{tabular}

\section{SELECTION}

\section{Identify causal relationships}

- Identify known or plausible relationships between the hazard, human health and wellbeing, and factors that make people more vulnerable to these impacts

\section{Create conceptual framework}

- Develop or select a conceptual framework for understanding social vulnerability to natural hazards

\section{Identify potential indicators}

- Review existing indicators (national and international), expert advice, one-off analyses that can be converted to indicators, and available datasets

- Identify potential indicators to fit the conceptual framework. Proxy indicators may be used for some aspects of the conceptual framework if necessary

- Identify potential point locations that may relate to the conceptual framework

- Ensure indicators fit conceptual framework and reflect casual relationships

\section{Evaluate potential indicators}

- Evaluate potential indicators against indicator selection criteria

- Obtain expert and end-user feedback

- Check alignment with other indicators in use and stakeholder needs

- Revise indicator list and obtain further expert feedback if required

\section{DESIGN AND IMPLEMENTATION}

Design the indicators and output methods

- Design the technical aspects of the indicator (eg indicator definitions)

- Identify ways of presenting the indicator data to meet the needs of key users

\section{Produce the indicators}

- Obtain end-user input into analysis and publication methods

- Analyse the data, and create data tables

- Create data visualisations using data tables

- Obtain expert feedback and peer review

- Publish data tables, data visualisations and metadata for indicators

Figure 2. Social vulnerability indicator development process (adapted from Mason et al. [52]). 


\subsubsection{Selection Stage}

The indicator selection stage identified a set of potential indicators that met the data and information needs found in the scoping stage. A fundamental approach for this stage was to use a conceptual framework to guide indicator selection [54]. Conceptual frameworks summarise concepts and how ideas are organized and relate to one another. Without a conceptual framework to guide indicator selection, indicator sets can be an eclectic mix of data-driven indicators, that make little sense together [54] and that are not balanced or relevant to the important underlying issues [53].

Our conceptual framework was developed for social vulnerability to natural hazards, based on existing frameworks of social vulnerability and resilience to natural hazards and climate change $[17,33,55]$. The framework was designed to be practical, with dimensions that were measurable and able to be used for guiding indicator selection, as well as taking into account climate change. Potential indicators were identified to measure the different dimensions of the conceptual framework, based on previous indicator sets, expert advice, and available datasets. A public health perspective was incorporated in the indicator selection process, with indicators focusing primarily on those indicators relevant to the potential impacts on people's health and wellbeing. The indicators were then evaluated against ten indicator selection criteria, based on previous statistical guides [54] and the EHINZ programme [52], and adapted to meet the specific needs of the end users (Table 1).

Table 1. Selection criteria for selecting social vulnerability indicators.

\begin{tabular}{|c|c|c|}
\hline Type & Selection Criteria & Details for the Social Vulnerability Indicators \\
\hline \multirow{4}{*}{ Data sources } & Data availability & $\begin{array}{l}\text { Data need to be currently available; not too } \\
\text { much work required to extract data }\end{array}$ \\
\hline & $\begin{array}{l}\text { Methodologically sound } \\
\text { measurement }\end{array}$ & $\begin{array}{l}\text { Data source needs to be reliable, accurate, and } \\
\text { representative of the population; minimal bias } \\
\text { and/or undercounting }\end{array}$ \\
\hline & Able to be disaggregated & $\begin{array}{l}\text { Data need to be available at a local level } \\
\text { (neighbourhoods if possible) }\end{array}$ \\
\hline & Timely & $\begin{array}{l}\text { Data need to be collected and reported } \\
\text { frequently, so that data are not too out of date }\end{array}$ \\
\hline \multirow{5}{*}{ Measurement of indicators } & Intelligible and easily interpretable & $\begin{array}{l}\text { Indicators should be not too complex to } \\
\text { understand, and should be able to be understood } \\
\text { by a wide range of end users }\end{array}$ \\
\hline & $\begin{array}{l}\text { Methodologically sound } \\
\text { measurement }\end{array}$ & $\begin{array}{l}\text { Indicator definition and measurement needs to } \\
\text { be robust, and should measure some aspect of } \\
\text { the social vulnerability dimension }\end{array}$ \\
\hline & $\begin{array}{l}\text { Consistent with other indicator } \\
\text { programmes }\end{array}$ & $\begin{array}{l}\text { Indicators would ideally align with other } \\
\text { indicator datasets already being used by end } \\
\text { users }\end{array}$ \\
\hline & Sensitive to change & $\begin{array}{l}\text { Indicators are sensitive to change, so that they } \\
\text { are measuring the current situation }\end{array}$ \\
\hline & Comparable over time & $\begin{array}{l}\text { Less of a priority for social vulnerability } \\
\text { indicators, although ideally indicators can be } \\
\text { interpreted in similar ways over time }\end{array}$ \\
\hline \multirow{2}{*}{$\begin{array}{l}\text { Indicator relevance and } \\
\text { appropriateness }\end{array}$} & Scientifically valid & $\begin{array}{l}\text { Robust evidence needed for why the indicators } \\
\text { are important (given the conceptual framework) }\end{array}$ \\
\hline & Public health impact & $\begin{array}{l}\text { Indicators need to relate to an issue of significant } \\
\text { public health impact for the country; if numbers } \\
\text { are too low nationally for an indicator, the } \\
\text { indicator may not be very helpful. }\end{array}$ \\
\hline
\end{tabular}


The decision on the final set of indicators involved an iterative process of identifying potential indicators, assessing the indicators against selection criteria, and testing the indicators with stakeholders to ensure their usefulness.

\subsubsection{Design and Implementation Stage}

The design and implementation stage included defining the indicators in detail, gathering and analysing the data, and preparing the final indicator outputs for end users. Considerations included the type of data output (for example, counts, rates, or summary indices) and geographical output (national, regional or local), depending on the needs of end users. In this stage, we developed a draft set of indicators, which were then visualised on maps for our case study area of Porirua, and assessed by stakeholders. Their comments and feedback were incorporated, and a final indicator set was created for the whole of New Zealand. Indicators were output at a range of geographical scales where possible, including meshblock (approximately 100 people), area unit (approximately 2000 people), territorial authority (of which there are 67 in New Zealand) and district health board ( 20 in New Zealand). Indicator data were output as both percentages of the population (to show relative impact) and counts of people (to show the number of people affected). In addition to the indicators, point locations relating to vulnerable populations (such as schools, rest homes and hospitals) were also identified through discussions with stakeholders, and guided by the conceptual framework.

The presentation of indicator outputs was also highly important, as indicator data needed to be accessible and meaningful to end users, and synthesise and communicate information, ideally in an informative and lively way [53]. Indicator datasets were produced in Microsoft Excel, and a range of dissemination methods for the indicator data were tested with stakeholders. As a result, 'heatmaps' were produced, by area unit for each local council, to show indicators for each social vulnerability dimension, coloured according to their relative value within the local council area. Online interactive maps and data visualisations were also created for Porirua with ESRI ArcGIS Story Maps and Tableau, showing maps of the indicators, as well as maps of point locations in relation to local flood hazard zones (incorporating 100 year climate change impacts). Metadata were also prepared for the final indicators, to provide detailed information about the indicators for end users.

\subsubsection{Stakeholder Engagement and Identifying Potential Uses for the Indicators}

Stakeholders provided feedback and input at various stages throughout the indicator development process, including on the study scope, their data needs, the conceptual framework, draft indicators, and indicator data visualisations. Three stakeholder workshops were held throughout the study, including one where stakeholders brainstormed ways that indicators could be used in the local context. We also met with members of the local Māori iwi (tribe), Ngāti Toa Rangatira, to discuss flooding impacts on their community and vulnerabilities and barriers to feeling resilient to flooding, and received their input on the study through an iwi representative and facilitator.

\section{Results}

\subsection{Developing a Conceptual Framework for Social Vulnerability}

We chose the MOVE framework as the basis for our conceptual framework to guide indicator selection, given its generic and holistic approach, its applicability to both natural hazards and climate change, and its proven utility as a framework to guide indicator selection. Therefore, our model incorporated the key elements of (i) exposure, (ii) susceptibility, and (iii) lack of resilience (Figure 3), from the MOVE framework. These key elements can be described as follows.

i. Exposure: Exposure refers to exposure to the hazard in both time and space, and can include direct, indirect and occupational exposure. 
ii. Susceptibility: We adopted the environmental health understanding, that people who are susceptible have a higher likelihood (or severity) of health impacts due to exposure to a hazard, compared with other people exposed to the same hazard [56]. Susceptibility can include innate susceptibility (largely due to genetic predisposition or physiology, such as children not having a fully developed immune system) and acquired susceptibility (through old age and/or illness) [56].

iii. Lack of resilience: In the context of social vulnerability, a 'lack of resilience' was interpreted at the individual level, to consider people's individual capacity to anticipate, cope and recover. For this, we incorporated the 'circle of capacities' [55]. Capacities can be understood as the assets and resources that people have (and are able to use), to prepare for, cope with, and recover from disasters [55]. The circle of capacities model shows a circle with six components: enough money to cope with crises/losses (economic resources), solidarity (social resources), strength, knowledge and skills to face hazards (human resources), safe housing and infrastructure (physical resources), enough food and water to cope with shortage (natural resources), and decision-making power (political resources) [55]. A lack of these capacities or resources may increase a person's vulnerability to natural hazards. These dimensions also align with practical functions and focuses of emergency management, such as providing financial assistance after a disaster. The circle of capacities was adapted for the New Zealand situation, with the input of stakeholders (Figure 3).

EXPOSURE

\begin{tabular}{|l|}
\hline $\begin{array}{l}\text { Exposure to } \\
\text { hazards }\end{array}$ \\
Direct impacts \\
Indirect impacts \\
(via essential \\
infrastructure) \\
Occupational \\
exposure
\end{tabular}

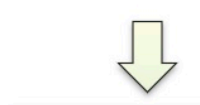

SUSCEPTIBILITY

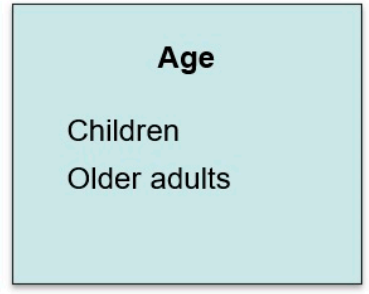

Health and disability

Physical health needs

Mental health needs

Disability

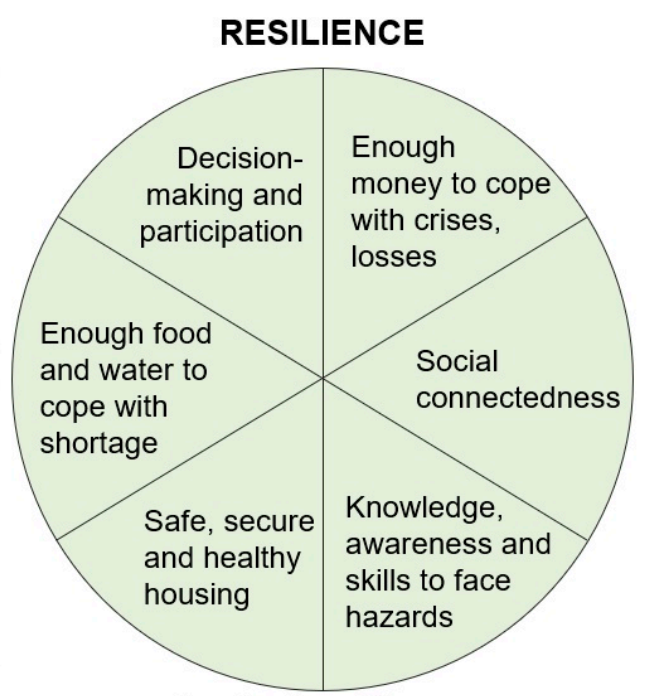

Lack of resilience
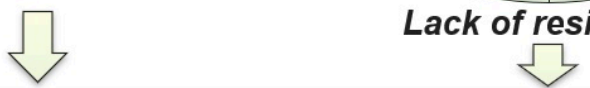

Vulnerability of human health and wellbeing to natural hazards

Impacts on health and wellbeing

physical, mental, social and spiritual health and wellbeing

Figure 3. Conceptual framework for social vulnerability to natural hazards (own figure, based on conceptual models by Birkmann et al. [33], USGCRP [17], Wisner et al. [46,55] and Durie [57]).

To reflect the risk to health and wellbeing risk from flooding, we used a holistic view of health, based on the Mãori indigenous model of health, 'Te whare tapa whā' (the house of four walls), which holds that hauora (wellbeing) is made of the four aspects of physical, mental, spiritual and social wellbeing [57]. This is similar to whole-life views of health of indigenous peoples in other countries, such as Australia [58] and Canada [59], as well 
as the World Health Organization's definition of health as 'a complete state of physical, mental and social wellbeing, and not merely the absence of disease or infirmity' [60].

Table 2 provides the rationale for each dimension of the framework, in terms of why people are more vulnerable to natural hazards.

Table 2. Dimensions of social vulnerability to natural hazards, and their rationale $[16,17,23-25,61,62]$.

\begin{tabular}{|c|c|}
\hline Social Vulnerability Dimension & Rationale \\
\hline Exposure & $\begin{array}{l}\text { Includes population groups exposed through direct impacts (such as living in a } \\
\text { flood hazard zone), indirect impacts (such as through disruption to essential } \\
\text { infrastructure and services, road transport networks, public transport, power } \\
\text { supplies), and occupational exposure. }\end{array}$ \\
\hline Children & $\begin{array}{l}\text { Children rely on caregivers to protect them, and they may not understand the } \\
\text { hazard or how to best react to it. Children are also more susceptible to certain } \\
\text { health impacts, as they are still growing and developing. }\end{array}$ \\
\hline Older adults & $\begin{array}{l}\text { Older adults often have pre-existing health conditions, and may be less mobile } \\
\text { and/or have vision or hearing loss. They may also experience social isolation. }\end{array}$ \\
\hline People with health needs and/or disability & $\begin{array}{l}\text { People with existing physical or mental health needs can be susceptible to the } \\
\text { stress and physical impacts of natural hazard events, and may also be } \\
\text { adversely impacted by disruptions to health services or medications. People } \\
\text { with disabilities may need others to help them, and may have difficulties } \\
\text { accessing emergency shelters. }\end{array}$ \\
\hline Enough money to cope with crises and losses & $\begin{array}{l}\text { People with low or no household income may not be able to afford } \\
\text { preparedness measures (such as insurance, stockpiling food, medications and } \\
\text { other resources), or be able to replace items after a natural hazard. }\end{array}$ \\
\hline Social connectedness & $\begin{array}{l}\text { Social isolation can leave people more vulnerable, as they may not have others } \\
\text { to help them when needed. By contrast, strong social connections and support } \\
\text { can provide resilience through networks and shared resources. }\end{array}$ \\
\hline Knowledge, skills and awareness to face hazards & $\begin{array}{l}\text { People are more vulnerable if they are not aware of hazards, not able to access } \\
\text { information, or do not know how to prepare or react during a hazard event. } \\
\text { Having knowledge, skills and awareness of hazards allows people to better } \\
\text { prepare for and cope during a natural hazard. }\end{array}$ \\
\hline Safe, secure and healthy housing & $\begin{array}{l}\text { Shelter, warmth and security are basic human needs. People living in } \\
\text { substandard housing, or in overcrowded housing, have increased risk of } \\
\text { experiencing negative impacts of natural hazards, and may find it difficult to } \\
\text { cope and recover. }\end{array}$ \\
\hline Food and water to cope with shortage & $\begin{array}{l}\text { Having sufficient food and water is a basic human need. After a natural } \\
\text { hazard, having access to these resources (e.g., through household } \\
\text { preparedness) is an important source of resilience. Not having enough } \\
\text { emergency food (or enough food on a daily basis) or water (e.g., piped water) } \\
\text { leaves people more vulnerable after a natural hazard. }\end{array}$ \\
\hline Decision making and participation & $\begin{array}{l}\text { Good leadership and decision making are vitally important before, during and } \\
\text { after a natural hazard. Furthermore, people's ability to access and participate } \\
\text { in decision making, and the inclusion of a diverse range of people in decision } \\
\text { making (especially vulnerable population groups and marginalised groups), is } \\
\text { important for ensuring their needs are met in emergency management } \\
\text { planning. Lack of involvement or inclusion in decision making can increase } \\
\text { people's vulnerability, as it means their needs may not be met or planned for } \\
\text { through mitigation plans. }\end{array}$ \\
\hline
\end{tabular}

Comparing our framework to other sets of social vulnerability indicators suggested that the dimensions aligned well with previous sets of social vulnerability indicators (see Appendix A). Common indicator topics across the sets of social vulnerability indicators included children, older adults, people with existing health conditions and/or disabilities, poverty, housing issues, and social isolation. 
Certain indicators from previous sets did not easily fit into the identified social vulnerability dimensions of our framework. Indicators about 'race' and 'ethnicity' $[25,27]$ are likely to represent marginalised groups who are more likely to lack political power and experience social and economic racism [23], which can increase their vulnerability via one or more of the dimensions in our framework. Similarly, while some indicator sets included 'women' as an indicator, this depends on the context; women can experience aspects of both vulnerability and resilience, therefore gender is not necessarily predictive of vulnerability [16]. Additionally, some indicator sets included community-level, structural or contextual factors in society, such as existence of early warning systems, single-sector economic dependence, infrastructure dependence, hazard planning, and land use planning, which did not refer directly to individuals or specific population groups.

\subsection{Identifying Indicators and Data Sources}

Potential social vulnerability indicators for flooding in New Zealand were then identified to represent all the dimensions of social vulnerability in the framework. A final set of indicators were identified that measured the different dimensions of social vulnerability, met the indicator selection criteria, and had data available (Table 3). Given the importance of having local-level data for end users, the primary data source used was the $2013 \mathrm{New}$ Zealand Census of Populations and Dwellings.

For measuring exposure, indicators were included about the population and ethnic groups, to provide context about the populations living in an area. Exposure indicators were also included relating to indirect impacts (such as people relying on public transport) and occupational exposure (such as people working in primary industries).

For some dimensions where no relevant data were available at the local level, proxy indicators were used, to ensure that each dimension had at least one indicator. Instead of using data on the number of pregnant women, the number of babies aged under 1 year was used as a proxy. Due to a lack of specific data for the food and water dimension, the following proxy indicators were used: households living in rental housing, singleparent households, and neighbourhood deprivation (New Zealand Index of Deprivation 2013) [63]. In New Zealand, these population groups are less likely to have household emergency preparedness [64], and are also more likely to experience household food insecurity (whereby households do not have sufficient food on a regular basis) [65]. For the decision-making dimension, no data were readily available at the very local level, so voting participation at the local council level was used instead. Health indicators relating to people with certain health conditions (such as cardiovascular disease, respiratory disease, and mental health issues) were not able to be completed within the timeframes of this study, but could be developed in the future.

For some dimensions, overlapping indicators were included (for example, 65+ years, $75+$ years, $85+$ years) in order to meet the varying data needs of end users. Additionally, indicators were included in all the dimensions that they were relevant for, which meant some indicators (such as NZDep) appeared in multiple dimensions. 
Table 3. Social vulnerability dimensions and indicators for flooding for New Zealand.

\begin{tabular}{|c|c|}
\hline Dimension of Social Vulnerability & Social Vulnerability Indicators \\
\hline Exposure (direct) & $\begin{array}{l}\text { Number of people } \\
\text { Number of households } \\
\text { Ethnic groups (European, Māori, Pacific peoples, Asian, Middle } \\
\text { Eastern/Latin American/African) }\end{array}$ \\
\hline Exposure (indirect) & $\begin{array}{l}\text { People who commute outside of the area } \\
\text { People who use public transport to get to and from work } \\
\text { People living in rural or remote communities }\end{array}$ \\
\hline Exposure (occupational) & $\begin{array}{l}\text { Health care workers and first responders } \\
\text { People working in the primary industries }\end{array}$ \\
\hline Children & $\begin{array}{l}\text { Children aged } 0-4 \text { years } \\
\text { Children aged } 0-14 \text { years }\end{array}$ \\
\hline Older adults & $\begin{array}{l}\text { People aged } 65+\text { years } \\
\text { People aged } 75+\text { years } \\
\text { People aged } 85+\text { years }\end{array}$ \\
\hline Health and disability & Pregnant women (proxy used of babies aged $<1$ year) \\
\hline Having enough money to cope with crises/losses & $\begin{array}{l}\text { Socioeconomic deprivation (NZDep2013 deciles) [63] } \\
\text { Single-parent households } \\
\text { Unemployed } \\
\text { Not in labour force } \\
\text { People with minimal education } \\
\text { Households with no car }\end{array}$ \\
\hline Social connectedness & $\begin{array}{l}\text { People who are new to the neighbourhood (within previous year) } \\
\text { Older adults (65+ years) living alone } \\
\text { Single-parent households } \\
\text { Single-person households } \\
\text { Households living in rental housing } \\
\text { Neighbourhoods with fewer households with children } \\
\text { Recent immigrants }\end{array}$ \\
\hline Knowledge, skills, and awareness of natural hazards & $\begin{array}{l}\text { People who are new to the neighbourhood (within previous year) } \\
\text { People with limited English proficiency } \\
\text { Recent immigrants } \\
\text { Households with no access to the internet } \\
\text { Households with no access to a mobile phone } \\
\text { Households with no access to a telephone }\end{array}$ \\
\hline Safe, secure and healthy housing & $\begin{array}{l}\text { Households living in rental housing } \\
\text { Crowded households } \\
\text { People living in crowded households } \\
\text { People who are homeless and/or severely housing deprived * }\end{array}$ \\
\hline $\begin{array}{c}\text { Enough food and water (and other essentials) to } \\
\text { survive }\end{array}$ & $\begin{array}{l}\text { Households living in rental housing } \\
\text { Single-parent households } \\
\text { Socioeconomic deprivation (NZDep2013) [63] }\end{array}$ \\
\hline Decision making and participation & Voter turnout in Local Authority elections * \\
\hline
\end{tabular}

* Data were only available at the territorial authority level. Note: Further indicator details are available in Appendix B.

\subsection{Point Locations Relating to Social Vulnerability}

In addition to indicators, relevant point locations for the different dimensions of social vulnerability were identified using the conceptual framework. These point locations included places that socially vulnerable people live or spend time at, and/or important places for these people. In particular, these locations included:

- Schools and early childhood centres;

- $\quad$ Rest homes;

- Health providers, including primary health care clinics, pharmacies and hospitals; 
- Marae, which are meeting houses for local Māori iwi;

- Visitor accommodation and temporary housing.

Other sites of social and/or spiritual significance to Māori were also included, such as urupā (cemeteries). Appendix B contains a full list of point locations by social vulnerability dimension.

\subsection{Design and Implementation of Indicators-Case Study of Porirua City}

The social vulnerability indicators were tested using the case study of Porirua City, with the heatmap of social vulnerability indicators highlighting some key geographic areas of vulnerability (Figure 4). Cannons Creek and Waitangirua had a higher level of vulnerability across multiple dimensions and indicators, including higher socioeconomic deprivation (scoring a 10 on the NZDep2013 decile, signifying the highest decile of deprivation), and higher levels of single-parent households, people not able to speak English, and households with no access to the internet. Other flood-prone areas, such as Elsdon-Takapūwāhia, Titahi Bay, Ascot Park and Porirua East also had higher levels of vulnerability across similar indicators, including single-parent households, socioeconomic deprivation, living in rental accommodation, and not having access to the internet. Porirua Central, while having a low population count, had high levels of people being new to the neighbourhood, and having no access to the internet, as well as higher levels of single-parent households and living in rental housing. In these neighbourhoods, local residents may not be aware of the risks, and, given their vulnerabilities, may have less capacity to prepare, cope and recover. Other areas, such as Papakowhai, were vulnerable primarily due to the susceptible populations (such as older adults) living there, and the higher percentage of people new to the area.

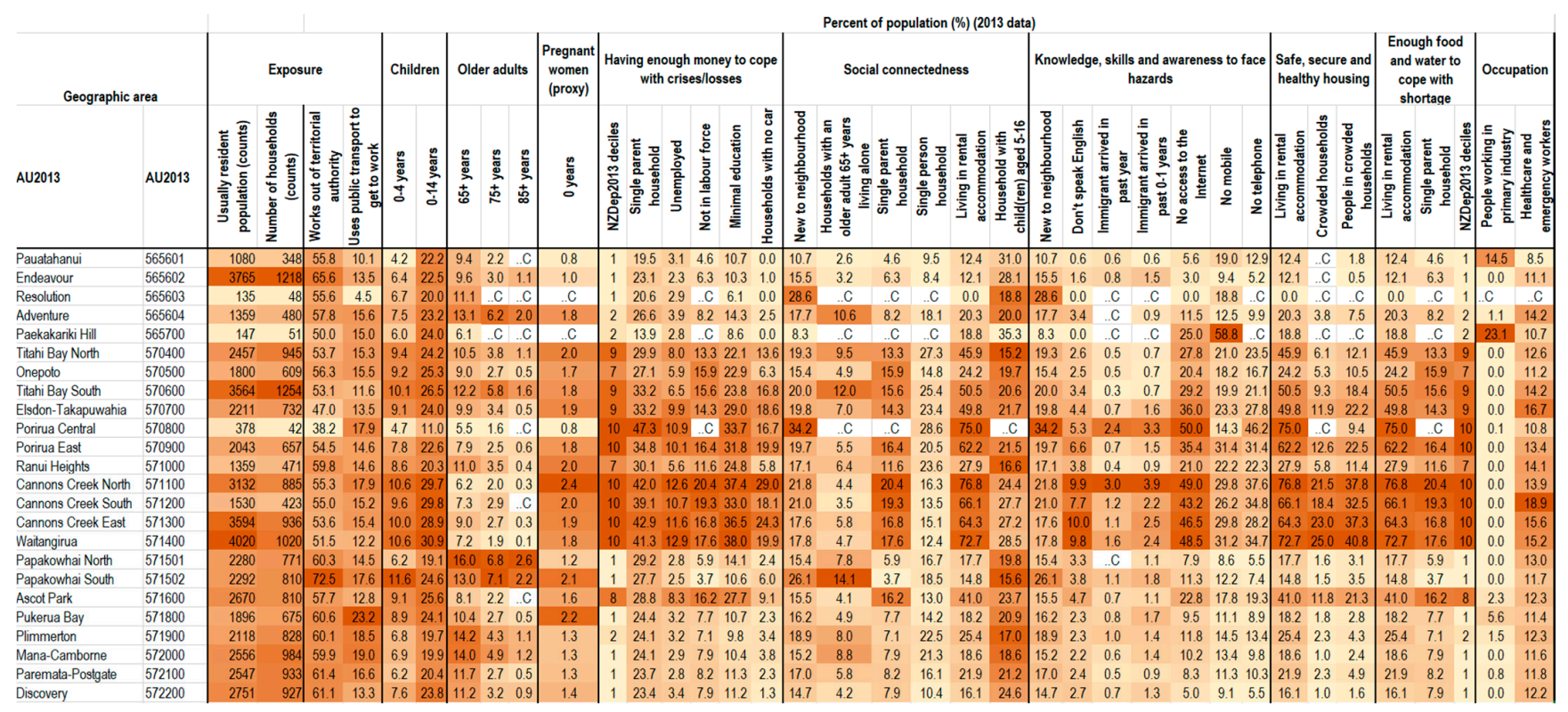

Figure 4. Social vulnerability indicators heatmap for Porirua City (2013 data by area unit (AU)) (more vulnerable areas are coloured darker) (screenshot). Note: .C denotes suppressed values due to low numbers. For the social connectedness indicator of households with child(ren) aged 5-16 years, higher values mean lower vulnerability, so lower values have been coloured darker.

The heatmap also allowed understanding of specific vulnerabilities. For example, across most areas of Porirua, there is a high percentage of working adults who commute outside of Porirua City for work, and/or use public transport to get to work. This information could be useful for understanding impacts of floods, such as disruptions to transportation networks. 
The social vulnerability indicators for Porirua City were also published on an online interactive map (Story Map), where individual indicators could be explored. For example, the online map of neighbourhood deprivation (NZDep2013 deciles) showed that many of the flood hazard zones were also areas with high deprivation, including Cannons Creek, Waitangirua, Porirua East and Takapūwāhia (Figure 5).

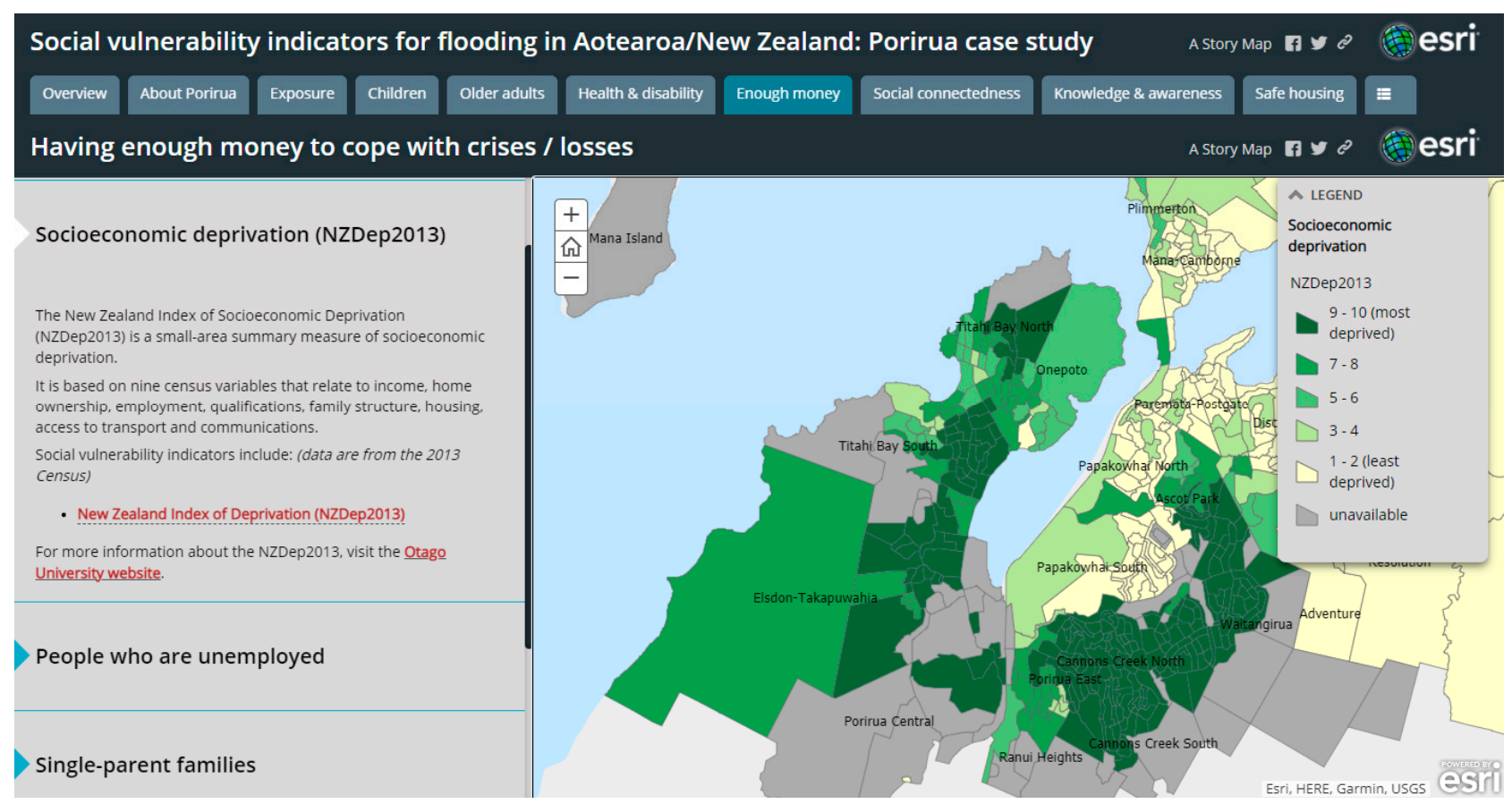

Figure 5. Screenshot of the online interactive map (Story Map) of social vulnerability indicators for Porirua, showing NZDep2013 at the meshblock level.

The social vulnerability indicators were complemented by maps of the flood hazard zones and locations of relevant point locations (such as schools and early childhood education centres (ECEs)). Figure 6 gives the example of Waitangirua, and shows that flood hazard zones affect much of the suburb, including several schools and early childhood education centres. The flood hazard and high levels of social vulnerability in this neighbourhood highlighted this geographic area as important for future risk reduction activities (such as flood management systems) and emergency preparedness and planning in order to meet the diverse needs of this neighbourhood.

\subsection{Identifying Potential Uses for the Social Vulnerability Indicators}

In response to these indicator outputs, stakeholders identified numerous ways that the social vulnerability indicators and data visualisations could be used. Firstly, the indicators could provide a structured way of thinking about and understanding social vulnerability to flooding, as well as objective measures of social vulnerability, before a flood event. Understanding the specific needs of vulnerable population groups could allow planning and readiness activities to be carried out in advance, to cater for these population groups. This could help support an equitable response to emergency preparedness, planning, response and recovery. The indicator data and data visualisations could also be used to spark discussion and initiate further data gathering at the local level.

During a flood event, social vulnerability indicators could provide information about the likely needs of the population for response activities, to help target and prioritise resources and efforts to areas with the highest needs, without needing to rely first on a ground survey. The indicators could also contribute to the development of shared situational awareness across the civil defence and emergency management response. After 
a flood, during the recovery phase, the indicators could help identify areas where people may need more support (e.g., financial support). Public health services and primary health care could also use the information to understand where socially vulnerable people live, to support health care provision.

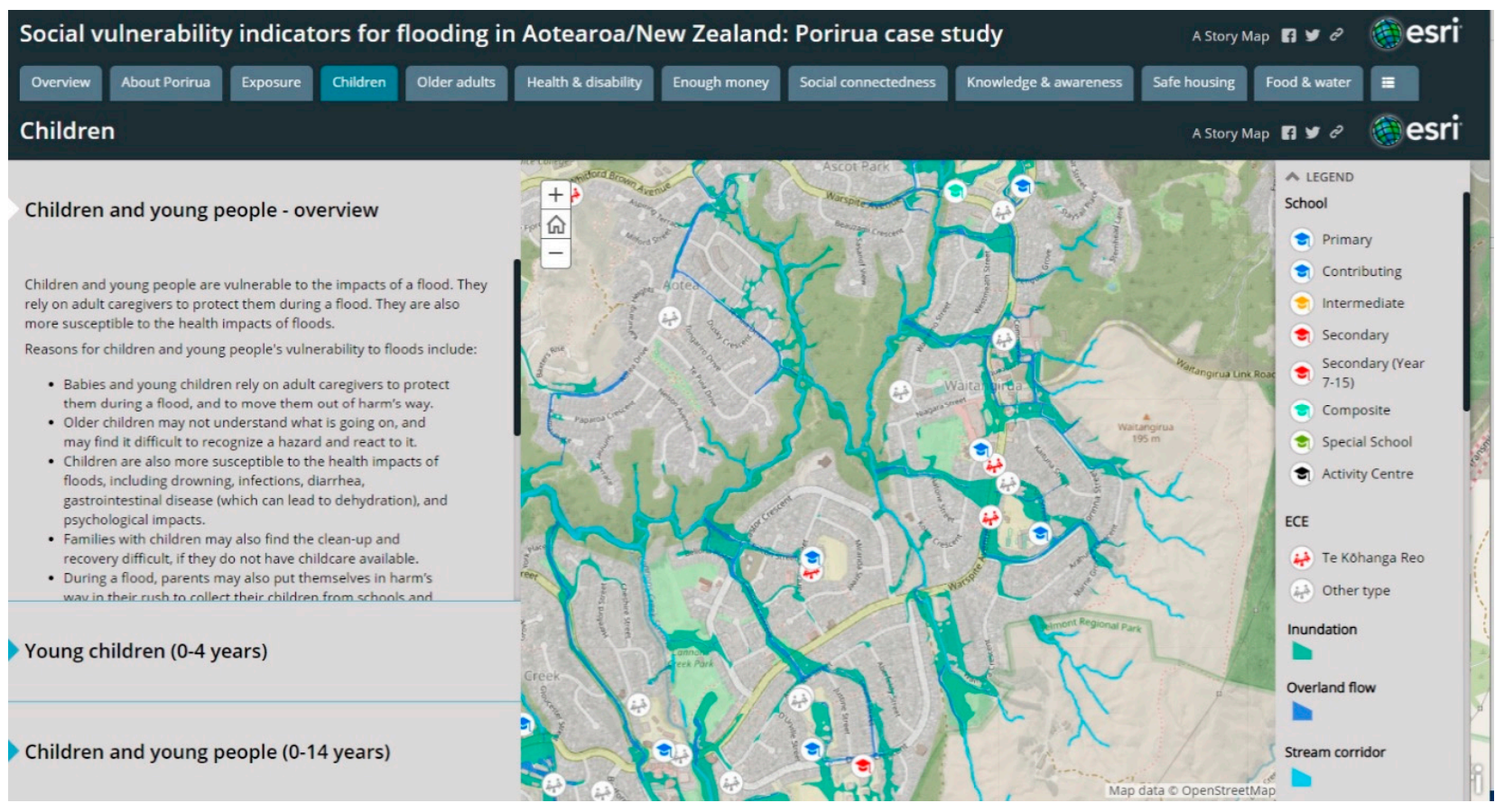

Figure 6. Screenshot of the online interactive map (Story Map) of flood hazard zones and school locations for Waitangirua, Porirua. Note: Flood hazard zones show 1-in-100 year flood extents, accounting for 100 year climate change impacts. Source: Wellington Water, Porirua City Council.

The indicators could also support important up-stream risk reduction efforts, including infrastructure upgrades, hazard mitigation, and provision of resilient housing in areas with large numbers of socially vulnerable people. For example, having objective data about social vulnerability could allow decision makers to consider factors other than economic impacts when deciding stormwater infrastructure upgrades. An extension of this study also identified how land use planning could mitigate the impacts of natural hazards for vulnerable populations, through restricting development in areas subject to natural hazards, restricting the location of critical buildings and vulnerable land uses (based on the point locations identified in this study) in areas subject to natural hazards, and requiring urban design that promotes resilience (such as connectivity of routes for evacuation) [66].

\section{Discussion}

\subsection{A New Set of Social Vulnerability Indicators for New Zealand}

This study has implemented the first national set of social vulnerability indicators for flooding in New Zealand. These indicators provide objective measures of social vulnerability related to flooding to inform disaster risk management activities for New Zealand civil defence practitioners, local councils, and health professionals, and may also be of interest to local residents.

The indicators align with similar sets of social vulnerability indicators for flooding, with indicators about children, older adults, health status, poverty, lower levels of education, unemployment, lack of vehicle, single-parent households, rental housing, household crowding, and limited English proficiency, similar to previous sets [23,25,27,31,32,34,35]. The New Zealand indicator set also included different, relevant indicators about singleperson households, recent immigrants, access to the internet, and people commuting 
outside of their local area for work, both to reflect the conceptual framework, and in response to feedback from stakeholders. The indicators also more generally reflect the vulnerable populations identified in the Sendai Framework for Disaster Risk Reduction 2015-2030 [67].

The indicators provide an important tool in managing disaster risk, by providing objective data about social vulnerability in the population to inform disaster risk reduction activities. For example, indicators about children, older adults, and people with health needs may be of particular interest to health providers, as these indicators represent populations who are more susceptible to health impacts. Indicators of poverty may show where welfare response and financial assistance is likely to be most helpful and could be prioritised during a response and recovery. Housing indicators may be useful when considering emergency housing during a response. Indicators about access to a motor vehicle, working outside of the area, and/or use of public transport, may be useful for understanding potential transportation and evacuation issues during a flooding event. Additionally, the point locations relating to social vulnerability can be combined with flood hazard zone information, to inform mitigation plans and support risk reduction activities, for example through land use planning, infrastructure upgrades and hazard mitigation works.

For the case study of Porirua, the indicators highlighted several critical geographic areas that had more vulnerable populations living in flood hazard zones, including Cannons Creek, Waitangirua, Elsdon-Takapūwāhia, Titahi Bay, Ascot Park, Porirua Central and Porirua East. Potential barriers to people developing resilience were identified, such as communities having a low level of internet access. This type of information could be used by civil defence emergency practitioners to guide how they interact with local neighbourhoods, for example by informing communications strategies.

More generally, indicator data are now also available for all areas of New Zealand, down to a small geographic scale, through online datasets and interactive online data visualisations. These datasets and data visualisations will allow end users to explore social vulnerability indicators for their local area, and allow similar assessments of vulnerability related to flood hazard to be carried out.

\subsection{The Value of Using a Conceptual Framework to Guide Indicator Selection}

Developing a conceptual framework for understanding social vulnerability was a crucial step in this study. While conceptual frameworks already existed for understanding vulnerability, resilience and capacities, this is the first time to our knowledge that these frameworks have been combined in this way to create a practical framework to guide selection of social vulnerability indicators for natural hazards. In particular, this study extends the application of the MOVE framework, to tease out what 'lack of resilience' may look like within the MOVE framework, in the context of social vulnerability. The use of well-established frameworks means that the conceptualisation of social vulnerability used in this study is robust and consistent with previous research. Using the MOVE framework also means the indicators are appropriate in the context of climate change.

Using a conceptual framework overcame several challenges often experienced when developing social vulnerability indicators. Firstly, the framework provides guidance on the topics that the indicators should cover, overcoming the difficulties of trying to directly replicate indicator sets from other parts of the world, which may not be relevant to New Zealand. Indicator topics in the framework include housing, social connectedness, knowledge of hazards, and economic wellbeing, as well as indicators about susceptible population groups, such as children, older adults, and people with health needs. While these topics are consistent with those included in other social vulnerability indicator sets, using the framework has the advantage of ensuring that the indicator set covers all dimensions of vulnerability.

Furthermore, the framework gives prominence to all aspects of vulnerability and resilience, regardless of data availability; each dimension is still represented as best it can 
with the data available. For example, decision making is highlighted as important in the circle of capacities [55] and the Sendai Framework, yet is often left out of social vulnerability indicator sets, or is indirectly represented through indicators of ethnicity, race or women. These variables are very country specific, and can reflect underlying vulnerabilities such as marginalisation, institutional racism, ongoing impacts of colonisation, and lack of representation in local body politics and emergency management groups. Recognising this with relevant indicators about ethnicity, race or women (in either the exposure or decision-making dimension), and/or wider variables such as voter turnout, can help reflect the underlying resilience factor of decision making.

The framework also provides a blueprint for ongoing development of indicators and improvements in data sources and data quality, and can highlight gaps in data sources. For example, when new data from the 2018 New Zealand Census of Populations and Dwellings became available after this study was completed, the framework could be used to guide indicator updates. When some indicators were unavailable to be updated due to a lack of data, replacement indicators could be selected to measure the same underlying dimensions of vulnerability. New indicators could also be identified to supplement existing indicators, for specific dimensions of social vulnerability.

\subsection{Limitations and Challenges}

One limitation of the indicator outputs from this study is that indicators are only indicators of reality, and therefore only show part of the picture of vulnerability and resilience for local communities. Additionally, in the response and recovery stages of a flood, the indicators will not give precise measurement of who is most affected, but they can provide initial information for action, before ground surveys can be carried out. The indicators also relate only to individual-level social vulnerability, rather than system-level factors, so will not include many factors that influence resilience at the system level. Nonetheless, these indicators can still be considered as some of the main factors contributing to individuallevel social vulnerability, and can be supported by and interpreted in the context of local knowledge and supplementary data from local areas, as well as information about wider social, community-level, macro-level and structural factors that influence vulnerability.

Major challenges for these indicators included data availability and data quality. Some social vulnerability dimensions were difficult to obtain neighbourhood-level data for, and therefore the best available data were used (for example, using voter turnout data at the local council level for the decision-making dimension), which could be supplemented with other local data by end users. Furthermore, some potential indicators (such as health indicators about the prevalence of chronic diseases) were unable to be implemented within the study time period, but could be developed at a later date. Additionally, this study originally aimed to use 2018 Census data, but data delays meant that older 2013 Census data had to be used instead. Nonetheless, the indicator framework allowed for indicator updates once the 2018 Census dataset was made publicly available.

There were also some changes to personnel in our stakeholder group during the two-year flood study, due to work commitments and job changes. This meant that some people came into the study at a later stage, without the previous background. However, their input was still highly valuable, and provided different perspectives at different time points throughout the study.

More broadly, while having multiple indicators allowed end users to understand the underlying vulnerabilities in an area, this approach does not provide a succinct summary value for a geographic area. We have tried to overcome this issue by using heatmaps to visually show the indicators across the social vulnerability dimensions at a single glance. However, an index could be developed from these indicators in future, informed by enduser feedback on indicators that are the most useful across multiple hazards, and that have the greatest impact on interventions. This approach would ensure the index itself is grounded in experience and end-user decisions about dimensions of vulnerability. 


\subsection{Extending the Use of the Social Vulnerability Indicators}

The approach used in this study could be applied in other jurisdictions to create social vulnerability indicators for flooding. The indicator development process provides a step-by-step guide for developing the indicators, with consideration of and input by stakeholders throughout the process. The conceptual framework could be used to guide indicator selection, with the dimensions of the framework prompting consideration of important topics, to ensure that these are all included as best as possible. While it is not expected that the New Zealand indicators would be directly useful in other countries, they could be used as a starting point, and adapted or replaced as needed.

This study has also laid the groundwork for a range of further work, in particular testing whether the framework and indicators could work for other hazards. Usefully, the conceptual framework has been developed for both natural hazards and climate change, and aligns with existing sets of social vulnerability indicators for natural hazards published internationally. A broad concept of vulnerability to natural hazards has been used, to incorporate the key elements of exposure, susceptibility, and lack of resilience, which are likely to apply to a range of hazards. Susceptible populations, such as children, older adults, and people with physical and/or mental health needs or a disability, will generally be more vulnerable to the negative impacts of any disaster. Furthermore, those people who lack resilience, in terms of a lack of money, social connectedness, hazard knowledge and skills, housing, emergency preparedness, and/or inclusion in decision making, are likely to be more vulnerable, regardless of the natural hazard. Given this, the framework and indicators may be relevant for other sudden-onset hazards, such as extreme weather events, wildfires, heatwaves, earthquakes and tsunami. Further work could test whether the framework would be appropriate across different hazards.

The indicators may also be useful for health emergencies, such as the infectious disease pandemic emergency of COVID-19. In the New Zealand context, potential impacts of COVID-19 include illness and death, as well as impacts from stress, lockdowns, and border closures (such as financial problems, job losses, potentially reduced access to health services and medication, mental health impacts, household crowding, and difficulties in accessing health services). Factors influencing high-risk groups in an influenza pandemic are similar to those for flooding, including poverty, single parents, substandard housing, crowded housing, children, immigrants, people with higher health needs or disabilities, older adults, and people with higher health needs, impaired immune systems or disabilities [68], as well as Māori and Pacific people in the New Zealand context [69]. Additionally, in countries with high levels of COVID-19, older adults aged 70 years and over appear to be at higher risk of experiencing severe illness and/or death if they contracted COVID-19. The similarity of vulnerability themes with the flooding indicators suggests that the social vulnerability indicators could be used for COVID-19 in New Zealand, with additional indicators about older adults aged 70 years and over, and people in occupations most likely to suffer economically due to the whole-of-society approach to managing the pandemic. Further work could test the utility of these indicators to the health sector.

Further work could also identify how well the indicators and framework work for longer-term climate-related disasters, such as drought and sea level rise. Some adaptations to the framework and additional indicators may be required, for example relating to people's longer-term adaptive capacity to climate change. Future vulnerability could also be considered, for example exposure to projected future hazard zones (taking into account the impacts of climate change), projected population demographic trends, and projected trends in vulnerability. Future causes of vulnerability could also be considered, such as a lack of ability to get insurance in hazard zones in the future.

\section{Conclusions}

This study has successfully created and implemented a set of social vulnerability indicators for flooding for New Zealand. Differently from many previous sets of social vulnerability indicators, we have developed a conceptual framework for social vulnera- 
bility to guide indicator selection. We identified the following ten dimensions relating to social vulnerability: exposure; children; older adults; health and disability status; having enough money to cope with crises and losses; social connectedness; skills, knowledge and awareness of natural hazards; safe, secure and healthy housing; enough food and water to cope with shortage; and decision making.

This study has filled an important information gap in New Zealand, as no set of social vulnerability indicators for natural hazards or flooding had previously been fully developed and implemented in the New Zealand context. Together, the social vulnerability indicators and the point locations provide valuable information for action in New Zealand, for example to strengthen local planning for emergencies, and to inform risk reduction activities and response efforts during a disaster. The indicators allow a multi-disciplinary approach to disaster risk reduction, highlighting the importance of emergency preparedness, housing, and social connectedness to improving peoples' resilience to natural hazards.

The approach used to develop these social vulnerability indicators could be applied in other jurisdictions, and could potentially be used with other hazards. In particular, the conceptual framework and indicators may work with other sudden-onset disasters, such as wildfires, heatwaves, earthquakes and tsunami, as well as pandemics such as COVID-19.

Author Contributions: Conceptualisation, K.M., K.L., B.B., D.R., and H.M.; methodology, K.M., K.L., and B.B.; mapping, C.H. and A.S.; data preparation, C.H. and K.M.; writing-original draft preparation, K.M.; writing - review and editing, K.L. and B.B.; project administration, B.B., K.M. and H.M. All authors have read and agreed to the published version of the manuscript.

Funding: This research was funded by the New Zealand Natural Hazards Research Platform (grant number C05 $\times$ 0907).

Institutional Review Board Statement: Not applicable.

Informed Consent Statement: Not applicable.

Data Availability Statement: Social vulnerability indicator data for New Zealand for 2013 are available from the URL: https:/ / www.ehinz.ac.nz/our-projects/social-vulnerability-indicators / (Accessed on 9 April 2021). Indicator data for 2013 are available as downloadable Excel files for New Zealand, and online data visualisations for Porirua. Updated social vulnerability indicator data for New Zealand for 2018 are available from the URL: https: / www.ehinz.ac.nz/indicators/population-vulnerability / social-vulnerability-to-natural-hazards/ (Accessed on 9 April 2021). Indicator data for 2018 are available as downloadable Excel files, and online data visualisations, for the whole of New Zealand.

Acknowledgments: We would like to thank the New Zealand Natural Hazards Research Platform for funding this study. We also acknowledge the support of the New Zealand Ministry of Health, through their funding of the Environmental Health Intelligence New Zealand (EHINZ) programme. We would like to thank the other researchers involved in this study, including Rawiri Faulkner (Tūtaiao Ltd., Wellington, New Zealand), James Beban, Sarah Gunnell (Urban Edge Planning Ltd., Wellington, New Zealand), Kristie-Lee Thomas (Geological and Nuclear Sciences, GNS Science, New Zealand) and Ben Popovich (National Institute of Water and Atmospheric Research, NIWA, New Zealand). We would also like to thank the many stakeholders we worked with on this study to design these indicators, and Ngāti Toa Rangatira for their support and input into this study. We would also like to thank Porirua City Council, Wellington Water and Statistics New Zealand for providing data for this study.

Conflicts of Interest: The authors declare no conflict of interest. The funders had no role in the design of the study; in the collection, analyses, or interpretation of data; in the writing of the manuscript, or in the decision to publish the results.

\section{Appendix A}

Comparison of dimensions of social vulnerability conceptual framework with previous sets of social vulnerability indicators. 
Table A1. Previous sets of international social vulnerability indicators, by social vulnerability dimension.

\begin{tabular}{|c|c|c|c|c|c|c|}
\hline \multirow[b]{2}{*}{$\begin{array}{l}\text { Social Vulnerability } \\
\text { Dimensions }\end{array}$} & \multicolumn{3}{|c|}{ Social Vulnerability Indicators for Natural Hazards } & \multicolumn{3}{|c|}{ Social Vulnerability Indicators for Flooding } \\
\hline & SoVI [27] & $\begin{array}{c}\text { Social Determinants of } \\
\text { Vulnerability Framework [25] }\end{array}$ & $\begin{array}{l}\text { Social Vulnerability Index for } \\
\text { Disaster Management [23] }\end{array}$ & $\begin{array}{l}\text { MOVE Framework for } \\
\text { Cologne Flood } \\
\text { Vulnerability [33] }\end{array}$ & $\begin{array}{l}\text { Urban Municipality Flood } \\
\text { Vulnerability Index [31] }\end{array}$ & $\begin{array}{l}\text { Social Flood Vulnerability } \\
\text { Index (Flood Hazard } \\
\text { Research Centre) [32] }\end{array}$ \\
\hline $\begin{array}{l}\text { Children and older } \\
\text { adults }\end{array}$ & Age & $\begin{array}{c}\text { Children } \\
\text { Older adults }(65+\text { years })\end{array}$ & $\begin{array}{c}0-17 \text { years } \\
65 \text { years and over }\end{array}$ & $\begin{array}{c}\text { Age structure (inability to } \\
\text { evacuate) }\end{array}$ & $\begin{array}{l}\text { Children }(<15 \text { years }) \\
\text { Older adults }(65+)\end{array}$ & Residents aged $75+$ years \\
\hline $\begin{array}{l}\text { Health and disability } \\
\text { status }\end{array}$ & & $\begin{array}{l}\text { People with disabilities } \\
\text { People with chronic and acute } \\
\text { medical illness }\end{array}$ & People with a disability & $\begin{array}{l}\text { Invalid (inability to } \\
\text { evacuate) }\end{array}$ & $\begin{array}{c}\text { Percent disabled } \\
\text { Composite health indicator }\end{array}$ & $\begin{array}{l}\text { Long-term sick-mobility } \\
\text { problems (restriction in } \\
\text { daily activities due to } \\
\text { long-term illness, handicap } \\
\text { or chronic disease) }\end{array}$ \\
\hline Having enough money & Personal wealth & $\begin{array}{l}\text { Low-to-no income } \\
\text { Less than high school diploma } \\
\text { Lack of vehicle }\end{array}$ & $\begin{array}{l}\text { Living below poverty line } \\
\text { Unemployment } \\
\text { Per capita income } \\
\text { No high school diploma } \\
\text { Single parents } \\
\text { No motor vehicle }\end{array}$ & $\begin{array}{l}\text { Households with } \\
\text { insurance against flood } \\
\text { damages }\end{array}$ & $\begin{array}{c}\text { Equivalised household income } \\
\% \text { below absolute poverty line } \\
\% \text { not working } \\
\% \text { with cars }\end{array}$ & $\begin{array}{c}\text { Financially deprived people } \\
\text { Unemployment among 16+ } \\
\text { years } \\
\text { Non-car ownership } \\
\text { Non-house ownership } \\
\text { No basis comfort } \\
\text { Single parents }\end{array}$ \\
\hline $\begin{array}{l}\text { Knowledge, skills and } \\
\text { awareness of hazards }\end{array}$ & & Limited English proficiency & $\begin{array}{l}\text { Minority groups } \\
\text { No high school diploma }\end{array}$ & $\begin{array}{l}\text { Duration of residence } \\
\text { (experience with floods) }\end{array}$ & $\begin{array}{c}\% \text { with mobile phone } \\
\% \text { with TV } \\
\% \text { with radio } \\
\text { Distance of municipality to } \\
\text { primary road }\end{array}$ & \\
\hline Safe housing & $\begin{array}{l}\text { Housing stock and } \\
\text { tenancy }\end{array}$ & Renters & $\begin{array}{l}\text { Multi-unit structures } \\
\text { Mobile homes } \\
\text { Household crowding }\end{array}$ & & $\begin{array}{c}\text { \% owner occupier } \\
\text { Presence of slums, tenements, } \\
\text { informal settlements } \\
\% \text { of houses constructed with } \\
\text { low-quality building material }\end{array}$ & $\begin{array}{l}\text { Overcrowding } \\
\text { Non-house ownership }\end{array}$ \\
\hline Enough food and water & & & & & $\begin{array}{c}\% \text { of households with piped } \\
\text { drinking water }\end{array}$ & \\
\hline $\begin{array}{l}\text { Other individual-level } \\
\text { (exposure/decision } \\
\text { making) }\end{array}$ & $\begin{array}{l}\text { Race-African } \\
\text { American, Asian } \\
\text { Ethnicity-Hispanic, } \\
\text { Native American }\end{array}$ & $\begin{array}{l}\text { People of colour } \\
\text { Women }\end{array}$ & Minority groups & & & \\
\hline
\end{tabular}


Table A1. Cont.

\begin{tabular}{|c|c|c|c|c|c|c|}
\hline \multirow[b]{2}{*}{$\begin{array}{l}\text { Social Vulnerability } \\
\text { Dimensions }\end{array}$} & \multicolumn{3}{|c|}{ Social Vulnerability Indicators for Natural Hazards } & \multicolumn{3}{|c|}{ Social Vulnerability Indicators for Flooding } \\
\hline & SoVI [27] & $\begin{array}{c}\text { Social Determinants of } \\
\text { Vulnerability Framework [25] }\end{array}$ & $\begin{array}{l}\text { Social Vulnerability Index for } \\
\text { Disaster Management [23] }\end{array}$ & $\begin{array}{c}\text { MOVE Framework for } \\
\text { Cologne Flood } \\
\text { Vulnerability [33] }\end{array}$ & $\begin{array}{l}\text { Urban Municipality Flood } \\
\text { Vulnerability Index [31] }\end{array}$ & $\begin{array}{l}\text { Social Flood Vulnerability } \\
\text { Index (Flood Hazard } \\
\text { Research Centre) [32] }\end{array}$ \\
\hline $\begin{array}{l}\text { Outside of framework } \\
\text { (structural/contextual) }\end{array}$ & $\begin{array}{l}\text { Density of the built } \\
\text { environment } \\
\text { Single-sector } \\
\text { economic } \\
\text { dependence } \\
\text { Infrastructure } \\
\text { dependence }\end{array}$ & & Living in group quarters & $\begin{array}{l}\text { Performance of early } \\
\text { warning system }\end{array}$ & $\begin{array}{c}\text { Housing/land use plan } \\
\text { indicating flood-prone areas } \\
\text { Risk plan for environmental } \\
\text { hazards } \\
\text { Preparedness for floods } \\
\% \text { of households with sewage } \\
\text { disposal system }\end{array}$ & \\
\hline
\end{tabular}

Table A2. Previous sets of social vulnerability indicators in New Zealand, by social vulnerability dimension.

\begin{tabular}{|c|c|c|c|c|}
\hline \multirow[b]{2}{*}{ Social Vulnerability Dimensions } & \multicolumn{2}{|c|}{ Indicator Sets for Social Vulnerability } & \multicolumn{2}{|c|}{ Indicator Sets for Resilience } \\
\hline & SVIs for Earthquakes in NZ (main set) [35] & $\begin{array}{l}\text { Vulnerability Assessment for the Hutt } \\
\text { Valley [34] }\end{array}$ & $\begin{array}{l}\text { New Zealand Resilience Index } \\
\text { (NZRI) [48] }\end{array}$ & $\begin{array}{l}\text { Bottom-up Approach for } \\
\text { Neighbourhood-Based Resilience } \\
\text { Framework [49] }\end{array}$ \\
\hline Children and older adults & $\begin{array}{c}\text { Children living in married couple families } \\
\text { Households receiving superannuation } \\
\text { Population aged } 0-4 \text { years } \\
\text { Population aged } 65+\text { years } \\
\text { Median age }\end{array}$ & $\begin{array}{l}\text { Children aged } 0-4 \text { years } \\
\text { Elderly aged } 65+\text { years }\end{array}$ & & \\
\hline Health and disability status & $\begin{array}{l}\text { Population living in nursing and } \\
\text { skilled-nursing facilities } \\
\text { Population with disability }\end{array}$ & $\begin{array}{l}\text { Population on sickness benefit } \\
\text { Population using NZ sign language }\end{array}$ & Hospitalisation rates & $\begin{array}{l}\text { Pre-existing and post-disaster mental and } \\
\text { emotional health of individuals }\end{array}$ \\
\hline
\end{tabular}


Table A2. Cont.

Social Vulnerability Dimension

SVIs for Earthquakes in NZ (main set) [35]

\section{Vulnerability Assessment for the Hut}

Valley [34] \\ Indicator Sets for Resilience}

New Zealand Resilience Index (NZRI) [48]
Bottom-up Approach for

Neighbourhood-Based Resilience Framework [49]

$$
\text { Poverty }
$$

Households with no car

Female-headed households

$$
\text { Renters }
$$

Having enough money

$$
\text { Unemploymen }
$$

Less than 12th grade education

Employment in service industry

Median house value

Households earning greater than $\$ X X X, X X X$$$
\text { annually }
$$

Per capita income

Female participation in labour force
Female-headed households

$$
\text { Renters }
$$

Single parents

Having 3+ children

No educational qualifications

Household/individual income

Receiving benefit

Unemployed

Working in sale and services, or primary

$$
\text { industry }
$$

No motor vehicle
Single parents

Less than a year in current residence
People working in fulltime employment

People with post-high school education

Household income (equivalised)
Financial health of individuals, households and the neighbourhood
Collective efficacy

Community participation

Place attachment

Social networks

Social responsibility

Cultural values and practices

Awareness of hazard risks

$$
\text { Self-efficacy }
$$

Community efficacy
Non-European No telecommunications access

$\begin{array}{cc}\begin{array}{c}\text { Knowledge, skills and awareness of } \\ \text { hazards }\end{array} & \begin{array}{c}\text { Speaking English as a second language with } \\ \text { limited English proficiency }\end{array} \\ \text { Less than a year in current residence } \\ \text { Living overseas } 5 \text { years ago }\end{array}$ hazards
Less than 12th grade education

English not first language

Long-term residency
Education and training on responding to disasters

Availability and accessibility of disaster risk information Diversity of skills

Past experiences of disasters and other adverse events

Understanding potential hazard impacts and consequences 
Table A2. Cont.

Indicator Sets for Social Vulnerability

Indicator Sets for Resilience

\section{New Zealand Resilience Index} (NZRI) [48]
Social Vulnerability Dimensions
SVIs for Earthquakes in NZ (main set) [35]

\section{Vulnerability Assessment for the Hut}

Valley [34]
Bottom-up Approach for

Neighbourhood-Based Resilience Framework [49]

$\%$ of households with emergency Personal responsibility for self-protection water for three days

(e.g., disaster preparedness)

\section{Females}

Other individual-level

(exposure/decision making)

Female

Ethnic populations-Māori, Pacific,

Asian, MELAA
Outside of framework

(structural/contextual)
Hospitals per capita
Economic sector diversity
Infrastructure independency

Infrastructure independency
systemic resilience metric

$\%$ commercial buildings that meet at

least $34 \%$ of building standard

Land use change between 1990 and

$$
2012
$$

Registered historic sites

damaged/destroyed since 2000

$\%$ completeness of hazard planning from district plans

Number of hospital beds per 1000 people

Average distance to designated

Community Emergency Response
Neighbourhood space and amenities Civic infrastructure

Experiences and effectiveness of collective action

Unifying leadership

Inclusiveness

Community planning

$$
\text { Centre }
$$




\section{Appendix B. Social vulnerability indicators for New Zealand}

Table A3. Social vulnerability indicators for flooding in New Zealand, full list, 2013 indicators.

\begin{tabular}{|c|c|c|c|}
\hline $\begin{array}{l}\text { Dimension of Social } \\
\text { Vulnerability }\end{array}$ & Social Vulnerability Indicators & Data Source & Indicator Details \\
\hline \multirow{3}{*}{ Exposure (direct) } & Number of people & 2013 Census & Usually resident population \\
\hline & Number of households & 2013 Census & Number of households \\
\hline & $\begin{array}{l}\text { Ethnic groups: (European, Māori, Pacific } \\
\text { peoples, Asian, Middle Eastern/Latin } \\
\text { American/African (MELAA) }\end{array}$ & 2013 Census & Total response ethnic groups \\
\hline \multirow{3}{*}{ Exposure (indirect) } & $\begin{array}{l}\text { People who regularly commute outside of } \\
\text { the area }\end{array}$ & 2013 Census & $\begin{array}{c}\text { People with a work address } \\
\text { located in different territorial } \\
\text { authority (TA) to residential } \\
\text { address }\end{array}$ \\
\hline & $\begin{array}{l}\text { People who use public transport to get to } \\
\text { and from work }\end{array}$ & 2013 Census & $\begin{array}{l}\text { People who used public transport } \\
\text { (train, bus, ferry) to get to work } \\
\text { on Census day }\end{array}$ \\
\hline & $\begin{array}{l}\text { People living in rural or remote } \\
\text { communities }\end{array}$ & 2013 Census & $\begin{array}{l}\text { People living in a rural centre or } \\
\text { rural area }\end{array}$ \\
\hline \multirow[b]{2}{*}{ Exposure (occupational) } & People working in the primary industries & 2013 Census & $\begin{array}{l}\text { People working in agriculture, } \\
\text { forestry or fishing }\end{array}$ \\
\hline & Health care workers and first responders & 2013 Census & $\begin{array}{l}\text { People working in health care and } \\
\text { social assistance, police services, } \\
\text { fire protection and other } \\
\text { emergency services, and } \\
\text { ambulance serivces }\end{array}$ \\
\hline Children & $\begin{array}{l}\text { Children aged } 0-4 \text { years } \\
\text { Children aged } 0-14 \text { years }\end{array}$ & 2013 Census & \\
\hline Older adults & $\begin{array}{l}\text { People aged } 65+\text { years } \\
\text { People aged } 75+\text { years } \\
\text { People aged } 85+\text { years }\end{array}$ & 2013 Census & \\
\hline
\end{tabular}

People with a pre-existing health condition (including heart disease, diabetes, high cholesterol, respiratory conditions, immunosuppression)

To be developed

eople requiring essential medications or

Physical health needs health services (such as angina medication, insulin, inhalers, epilepsy medication, immunosuppressant drugs, anti-HIV drugs, dialysis, home oxygen therapy cancer treatment)

$$
\text { Pregnant women }
$$

2013 Census

To be developed

People accessing mental health services in the past year

To be developed

People requiring essential medication for
mental illness (anti-depressants, anti-anxiety medication, anti-psychotics, opioid substitution treatment)

Mental health needs

People with substance abuse issues

To be developed

To be developed

People with a disability (mobility, hearing,

Disability
To be developed 
Table A3. Cont.

\begin{tabular}{|c|c|c|c|}
\hline $\begin{array}{l}\text { Dimension of Social } \\
\text { Vulnerability }\end{array}$ & Social Vulnerability Indicators & Data Source & Indicator Details \\
\hline \multirow{6}{*}{$\begin{array}{l}\text { Having enough money to } \\
\text { cope with crises/losses }\end{array}$} & Socioeconomic deprivation & Atkinson et al. [63] & $\begin{array}{c}\text { New Zealand Index of } \\
\text { Deprivation } 2013 \text { (NZDep2013) } \\
\text { deciles }\end{array}$ \\
\hline & Single-parent households & 2013 Census & $\begin{array}{c}\text { Households with one parent with } \\
\text { child(ren) }\end{array}$ \\
\hline & Unemployed & 2013 Census & $\begin{array}{l}\text { People who were unemployed, } \\
\text { among those aged } 15+\text { years }\end{array}$ \\
\hline & Not in labour force & 2013 Census & $\begin{array}{l}\text { People who were not in the labour } \\
\text { force, among those aged } 15+\text { years }\end{array}$ \\
\hline & People with minimal education & 2013 Census & $\begin{array}{l}\text { People with no qualification, } \\
\text { among those aged } 15+\text { years }\end{array}$ \\
\hline & Households with no access to car & 2013 Census & $\begin{array}{l}\text { Households with no motor } \\
\text { vehicle }\end{array}$ \\
\hline \multirow{7}{*}{ Social connectedness } & $\begin{array}{l}\text { People who are new to the neighbourhood } \\
\text { (e.g., within previous year) }\end{array}$ & 2013 Census & Years at usual residence $<1$ year \\
\hline & Older adults living alone & 2013 Census & $\begin{array}{l}\text { Adults aged } 65+\text { years living in a } \\
\text { single-person household }\end{array}$ \\
\hline & Single-parent households & 2013 Census & $\begin{array}{l}\text { Households with a single parent } \\
\text { and dependent children }\end{array}$ \\
\hline & Single-person households & 2013 Census & Households with only one person \\
\hline & Households living in rental housing & 2013 Census & $\begin{array}{l}\text { Dwellings not owned and not } \\
\text { held in family trust }\end{array}$ \\
\hline & $\begin{array}{l}\text { Neighbourhoods with fewer households } \\
\text { with children }\end{array}$ & 2013 Census & $\begin{array}{l}\text { Households with one or more } \\
\text { children* }\end{array}$ \\
\hline & Recent immigrants & 2013 Census & $\begin{array}{c}\text { People who moved to New } \\
\text { Zealand recently }(<1 \text { year, } \\
<2 \text { years })\end{array}$ \\
\hline \multirow{5}{*}{$\begin{array}{l}\text { Knowledge, skills, and } \\
\text { awareness of natural hazards }\end{array}$} & $\begin{array}{l}\text { People who are new to the neighbourhood } \\
\text { (within previous year) }\end{array}$ & 2013 Census & Years at usual residence $<1$ year \\
\hline & $\begin{array}{l}\text { Households with no access to a mobile } \\
\text { phone }\end{array}$ & 2013 Census & $\begin{array}{l}\text { Households that did not have } \\
\text { access to a mobile phone }\end{array}$ \\
\hline & Households with no access to the internet & 2013 Census & $\begin{array}{l}\text { Households that did not have } \\
\text { access to the internet }\end{array}$ \\
\hline & People with limited English proficiency & 2013 Census & $\begin{array}{c}\text { People who reported not speaking } \\
\text { English }\end{array}$ \\
\hline & Recent immigrants & 2013 Census & $\begin{array}{c}\text { People who moved to New } \\
\text { Zealand recently (<1 year, } \\
<2 \text { years })\end{array}$ \\
\hline \multirow{4}{*}{$\begin{array}{l}\text { Safe, secure and healthy } \\
\text { housing }\end{array}$} & Households living in rental housing & 2013 Census & $\begin{array}{l}\text { Dwellings not owned and not } \\
\text { held in family trust }\end{array}$ \\
\hline & Crowded households & 2013 Census & $\begin{array}{l}\text { Households that needed } 1+ \\
\text { bedrooms, according to the } \\
\text { Canadian National Occupancy } \\
\text { Standard }\end{array}$ \\
\hline & People living in crowded households & 2013 Census & $\begin{array}{l}\text { People living in households that } \\
\text { needed } 1+\text { bedrooms, according } \\
\text { to the Canadian National } \\
\text { Occupancy Standard }\end{array}$ \\
\hline & $\begin{array}{c}\text { People in severe housing deprivation } \\
\text { (homelessness) }\end{array}$ & Amore et al. 2016 [70] & $\begin{array}{c}\text { People who were severely } \\
\text { housing deprived (or homeless) in } \\
2013 \text { (only available at territorial } \\
\text { authority level) }\end{array}$ \\
\hline
\end{tabular}


Table A3. Cont.

\begin{tabular}{cccc}
\hline $\begin{array}{c}\text { Dimension of Social } \\
\text { Vulnerability }\end{array}$ & Social Vulnerability Indicators & Data Source & Indicator Details \\
\hline & Households living in rental housing & 2013 Census & $\begin{array}{c}\text { Dwellings not owned and not } \\
\text { held in family trust }\end{array}$ \\
\cline { 2 - 4 } $\begin{array}{c}\text { Enough food and water (and } \\
\text { other essentials) to survive }\end{array}$ & Single-parent households & 2013 Census & $\begin{array}{c}\text { Households with a single parent } \\
\text { and dependent children }\end{array}$ \\
\cline { 2 - 4 } & Socioeconomic deprivation & Atkinson et al. [63] & $\begin{array}{c}\text { New Zealand Index of } \\
\text { Deprivation 2013 (NZDep2013) } \\
\text { deciles }\end{array}$ \\
\hline $\begin{array}{c}\text { Decision making and } \\
\text { participation }\end{array}$ & Voter turnout in local elections & NZ Department of Internal & $\begin{array}{c}\text { Residential voter turnout in the } \\
\text { 2016 Local Body elections * (only } \\
\text { available at territorial authority level) }\end{array}$ \\
\hline
\end{tabular}

* Indicator relates to positive impact, so higher values should be interpreted as lower vulnerability. For all other indicators, higher values relate to higher vulnerability.

Table A4. Point locations relating to social vulnerability for flooding for New Zealand.

\begin{tabular}{|c|c|}
\hline Dimension of Social Vulnerability & Point Locations Examples \\
\hline Exposure (direct) & Emergency shelters \\
\hline Exposure (indirect) & $\begin{array}{l}\text { Main/arterial roads } \\
\text { Public transport networks (bus routes, train tracks, train stations) } \\
\text { Fire stations, police stations, ambulance stations } \\
\text { Important utilities (power substations, water pumping stations, etc.) } \\
\text { Hazardous substances facilities and contaminated sites }\end{array}$ \\
\hline Children & $\begin{array}{l}\text { Schools } \\
\text { Early childhood education centres }\end{array}$ \\
\hline Older adults & $\begin{array}{l}\text { Rest homes } \\
\text { Social housing for older adults }\end{array}$ \\
\hline Physical health needs & $\begin{array}{l}\text { Primary health care facilities } \\
\text { Pharmacies } \\
\text { Hospitals } \\
\text { Medical supply depots } \\
\text { Other health facilities (dialysis units, birthing units, long-stay hospitals) }\end{array}$ \\
\hline Mental health needs & $\begin{array}{l}\text { Mental health services } \\
\text { Primary health care facilities } \\
\text { Pharmacies } \\
\text { Hospitals }\end{array}$ \\
\hline Disability & $\begin{array}{l}\text { Community residential homes } \\
\text { Respite care facilities } \\
\text { Specialist schools for children with disabilities and high needs }\end{array}$ \\
\hline $\begin{array}{l}\text { Having enough money to cope with } \\
\text { crises/losses }\end{array}$ & $\begin{array}{l}\text { Social housing } \\
\text { Hazard areas where properties are not able (or prohibitively expensive) to be insured }\end{array}$ \\
\hline Social connectedness & $\begin{array}{l}\text { Schools } \\
\text { Early childhood centres } \\
\text { Churches } \\
\text { Local meeting places (such as marae) }\end{array}$ \\
\hline $\begin{array}{l}\text { Knowledge, skills, and awareness of natural } \\
\text { hazards }\end{array}$ & $\begin{array}{l}\text { Visitor accommodation, such as motels, hotels, camping grounds } \\
\text { Refugee settlement centres and locations }\end{array}$ \\
\hline Safe, secure and healthy housing & $\begin{array}{l}\text { Houses in flood hazard zones } \\
\text { Emergency housing (night shelters, women's refuge) } \\
\text { Temporary accommodation (camping grounds, boarding houses, etc.) }\end{array}$ \\
\hline $\begin{array}{l}\text { Enough food and water (and other essentials) } \\
\text { to survive }\end{array}$ & $\begin{array}{l}\text { Food stores } \\
\text { Food banks } \\
\text { Local emergency water supplies }\end{array}$ \\
\hline Decision making and participation & $\begin{array}{l}\text { Marae } \\
\text { Community Emergency Hubs }\end{array}$ \\
\hline $\begin{array}{l}\text { Group quarters and/or institutions (related to } \\
\text { housing) }\end{array}$ & $\begin{array}{l}\text { Prisons and youth justice facilities } \\
\text { Community correction centres } \\
\text { University dorms } \\
\text { Military quarters }\end{array}$ \\
\hline
\end{tabular}




\section{References}

1. Seneviratne, S.I.; Nicholls, N.; Easterling, D.; Goodess, C.M.; Kanae, S.; Kossin, J.; Luo, Y.; Marengo, J.; McInnes, K.; Rahimi, M.; et al. Changes in climate extremes and their impacts on the natural physical environment. In Managing the Risks of Extreme Events and Disasters to Advance Climate Change Adaptation: A Special Report of Working Groups I and II of the Intergovernmental Panel on Climate Change (IPCC); Field, C.B., Barros, V., Stocker, T.F., Qin, D., Dokken, D.J., Ebi, K.L., Mastrandrea, M.D., Mach, K.J., Plattner, G.-K., Allen, S.K., et al., Eds.; Cambridge University Press: Cambridge, UK; New York, NY, USA, 2012 ; pp. $109-230$.

2. Revi, A.; Satterthwaite, D.; Aragón-Durand, F.; Corfee-Morlot, J.; Kiunsi, R.; Pelling, M.; Roberts, D.; Solecki, W. Urban areas. In Climate Change 2014: Impacts, Adaptation, and Vulnerability. Part A: Global and Sectoral Aspects. Contribution of Working Group II to the Fifth Assessment Report of the International Panel on Climate Change; Field, C., Barros, V., Dokken, D., Mach, K., Mastrandrea, M.D., Bilir, T., Chatterjee, M., Ebi, K., Estrada, Y., Genova, R., et al., Eds.; Cambridge University Press: Cambridge, UK; New York, NY, USA, 2014; pp. 535-612.

3. UNDP. Social Vulnerability Assessment Tools for Climate Change and DRR Programming: A Guide to Practitioners; United Nations Development Programme: Istanbul, Turkey, 2017.

4. Royal Society of New Zealand. Climate Change Implications for New Zealand; Royal Society of New Zealand: Wellington, New Zealand, 2016.

5. MCDEM. Working from the Same Page: Consistent Messages for CDEM; Ministry of Civil Defence and Emergency Management: Wellington, New Zealand, 2010.

6. ICNZ. Cost of Natural Disasters. Available online: https://www.icnz.org.nz/natural-disasters/cost-of-natural-disasters/ (accessed on 1 October 2018).

7. Smith, W.; Davies-Colley, C.; Mackay, A.; Bankoff, G. Social impact of the 2004 Manawatu floods and the 'hollowing out' of rural New Zealand. Disasters 2011, 35, 540-553. [CrossRef]

8. Spee, K. Community Recovery after the 2005 Matata Disaster: Long-Term Psychological and Social Impacts; GNS Science Report 2008/12; GNS Science: Lower Hutt, New Zealand, 2008.

9. Saunders, W.; Coomer, M. Bay of Plenty July 2004 Flooding: Tabulated Results of a Survey of Residents; GNS Science Report 2006/20; GNS Science: Lower Hutt, New Zealand, 2006.

10. NIWA. Flood pains. Water Atmos. 2015, 2015, 10-19.

11. Reisinger, A.; Kitching, R.; Chiew, F.; Hughes, L.; Newton, P.; Schuster, S. Australasia. In Climate Change 2014: Impacts, Adaptation, and Vulnerability. Part B: Regional Aspects Contribution of Working Group II to the Fifth Assessment Report of the Intergovernmental Panel on Climate Change; Barros, V., Field, C., Dokken, D., Mastrandrea, M., Mach, K., Bilir, T., Chatterjee, M., Ebi, K., Estrada, Y., Genova, R., et al., Eds.; Cambridge University Press: Cambridge, UK; New York, NY, USA, 2014.

12. Alderman, K.; Turner, L.R.; Tong, S. Floods and human health: A systematic review. Environ. Int. 2012, 47, 37-47. [CrossRef] [PubMed]

13. Du, W.; FitzGerald, G.J.; Clark, M.; Hou, X.Y. Health impacts of floods. Prehosp. Disaster Med. 2010, 25, 265-272. [CrossRef] [PubMed]

14. March, G. Natural Disasters and the Impacts on Health; University of Western Ontario: London, ON, Canada, 2002.

15. Paterson, D.L.; Wright, H.; Harris, P.N.A. Health risks of flood disasters. Clin. Infect. Dis. 2018, 67, 1450-1454. [CrossRef] [PubMed]

16. Rufat, S.; Tate, E.; Burton, C.G.; Maroof, A.S. Social vulnerability to floods: Review of case studies and implications for measurement. Int. J. Disaster Risk Reduct. 2015, 14, 470-486. [CrossRef]

17. USGCRP. The Impacts of Climate Change on Human Health in the United States: A Scientific Assessment; U.S. Global Change Research Program: Washington, DC, USA, 2016.

18. Blake, D.; Lyons, A. Opioid Substitution Treatment Planning in a Disaster Context: Perspectives from Emergency Management and Health Professionals in Aotearoa/New Zealand. Int. J. Environ. Res. Public Health 2016, 13, 1122. [CrossRef] [PubMed]

19. Floods in the WHO European Region: Health Effects and Their Prevention; Menne, B.; Murray, V. (Eds.) World Health Organization Regional Office for Europe: Copenhagen, Denmark, 2013.

20. Prezant, B.; Douwes, J. Calculating the Burden of Disease Attributable to Indoor Dampness in New Zealand. 2011. Available online: http:/ / www.academia.edu/27232468/Calculating_the_burden_of_disease_attributable_to_indoor_dampness_in_NZ (accessed on 28 May 2018).

21. Clemens, P.; Hietala, J.; Rytter, M.; Schmidt, R.; Reese, D. Risk of domestic violence after flood impact: Effects of social support, age, and history of domestic violence. Appl. Behav. Sci. Rev. 1999, 7, 199-206. [CrossRef]

22. Houghton, R. "We Had to Cope with What We Had": Agency Perspectives on Domestic Violence and Disasters in New Zealand; Victoria University of Wellington: Wellington, New Zealand, 2010.

23. Flanagan, B.E.; Gregory, E.W.; Hallisey, E.J.; Heitgerd, J.L.; Lewis, B. A Social Vulnerability Index for Disaster Management. J. Homel. Secur. Emerg. Manag. 2011, 8. [CrossRef]

24. Rygel, L.; O'Sullivan, D.; Yarnall, B. A method for constructing a social vulnerability index: An application to hurricane storm surges in a developed country. Mitig. Adapt. Strateg. Glob. Chang. 2006, 11, 741-764. [CrossRef]

25. Atyia Martin, S. A framework to understand the relationship between social factors that reduce resilience in cities: Application to the City of Boston. Int. J. Disaster Risk Reduct. 2015, 12, 53-80. [CrossRef]

26. Wolkin, A.; Patterson, J.; Harris, S.; Soler, E.; Burrer, S.; McGeehin, M.; Greene, S. Reducing public health risk during disasters: Identifying social vulnerabilities. J. Homel. Secur. Emerg. Manag. 2015, 12, 809-822. [CrossRef] [PubMed] 
27. Cutter, S.L.; Boruff, B.J.; Shirley, W.L. Social vulnerability to environmental hazards. Soc. Sci. Q. 2003, 84, 242-261. [CrossRef]

28. MCDEM. National Disaster Resilience Strategy; Ministry of Civil Defence \& Emergency Management: Wellington, New Zealand, 2019.

29. Combaz, E. Disaster Resilience: Topic Guide; GSDRC, University of Birmingham: Birmingham, UK, 2014.

30. Cutter, S.L. Vulnerability to environmental hazards. Prog. Hum. Geogr. 1996, 20, 529-539. [CrossRef]

31. Rasch, R. Assessing urban vulnerability to flood hazard in Brazilian municipalities. Environ. Urban. 2016, 28, 145-168. [CrossRef]

32. Tapsell, S.M.; Penning-Rowsell, E.C.; Tunstall, S.M.; Wilson, T.L. Vulnerability to flooding: Health and social dimensions. Philos. Trans. R. Soc. Lond. Ser. A Math. Phys. Eng. Sci. 2002, 360, 1511-1525. [CrossRef]

33. Birkmann, J.; Cardona, O.D.; Carreño, M.L.; Barbat, A.H.; Pelling, M.; Schneiderbauer, S.; Kienberger, S.; Keiler, M.; Alexander, D.; Zeil, P.; et al. Framing vulnerability, risk and societal responses: The MOVE framework. Nat. Hazards 2013, 67, 193-211. [CrossRef]

34. Khan, S. Vulnerability assessment and their planning implications: A case study of the Hutt Valley, New Zealand. Nat. Hazards 2012, 64, 1587-1607. [CrossRef]

35. Kwok, A. Integrating Social Vulnerability Indicators in RiskScape's Earthquake Risk Modelling. GNS Sci. Rep. 2016, $2016,58$.

36. Cutter, S.L. The landscape of disaster resilience indicators in the USA. Nat. Hazards 2016, 80, 741-758. [CrossRef]

37. Paton, D.; Johnston, D.; Saunders, W. Mapping social vulnerability to natural hazards using GIS. Plan. Q. 2006, 160, 6-8.

38. Saulnier, D.; Dixit, A.; Nunes, A.; Murray, V. WHO Guidance on Research Methods for Health Emergency and Disaster Risk Management: Disaster Risk Factors-Hazards, Exposure and Vulnerability. 2020. Available online: https://extranet.who. int/kobe_centre/sites/default/files/pdf/WHO\%20Guidance_Research\%20Methods_Health-EDRM_3.2.pdf (accessed on 27 February 2021).

39. UNDRR. Terminology: Disaster Risk. Available online: https://www.undrr.org/terminology/disaster-risk (accessed on 25 February 2021).

40. Oppenheimer, M.; Campos, M.; Warren, R.; Birkmann, J.; Luber, G.; O’Neill, B.; Takahashi, K. Emergent risks and key vulnerabilities. In Climate Change 2014: Impacts, Adaptation, and Vulnerability. Part A: Global and Sectoral Aspects. Contribution of Working Group II to the Fifth Assessment Report of the Intergovernmental Panel on Climate Change; Field, C., Barros, V., Dokken, D., Mach, K., Mastrandrea, M., Bilir, T., Chatterjee, M., Ebi, K., Estrada, Y., Genova, R., et al., Eds.; Cambridge University Press: Cambridge, UK; New York, NY, USA, 2014; pp. 1039-1099.

41. Wisner, B.; Blaikie, P.; Cannon, T.; Davis, I. At Risk: Natural Hazards, People's Vulnerability and Disasters, 2nd ed.; Routledge: London, UK; New York, NY, USA, 2004.

42. Turner, B.; Kasperson, R.; Matson, P.; McCarthy, J.; Corell, R.; Christensen, L.; Eckley, N.; Kasperson, J.; Luers, A.; Martello, M.; et al. A framework for vulnerability analysis in sustainability science. Proc. Natl. Acad. Sci. USA 2003, 100, 8074-8079. [CrossRef]

43. Cardona, O.D.; van Aalst, M.K.; Birkmann, J.; Fordham, M.; McGregor, G.; Perez, R.; Pulwarty, R.S.; Schipper, E.L.F.; Sinh, B.T. Determinants of risk: Exposure and vulnerability. In A Special Report of Working Groups I and II of the Intergovernmental Panel on Climate Change (IPCC); Field, C.B., Barros, V., Stocker, T.F., Qin, D., Dokken, D.J., Ebi, K.L., Mastrandrea, M.D., Mach, K.J., Plattner, G.-K., Allen, S.K., et al., Eds.; Cambridge University Press: Cambridge, UK; New York, NY, USA, 2012; pp. 65-108.

44. Morimoto, T. Spatial analysis of social vulnerability to floods based on the MOVE framework and information entropy method: Case study of Katsushika Ward, Tokyo. Sustainability 2019, 11, 529.

45. Kablan, M.; Dongo, K.; Coulibaly, M. Assessment of social vulnerability to flood in urban Côte d'Ivoire using the MOVE framework. Water 2017, 9, 292. [CrossRef]

46. Salmond, C.; Crampton, P. NZDep2001 Index of Deprivation User's Manual; Department of Public Health, Wellington School of Medicine and Health Sciences: Wellington, New Zealand, 2002.

47. Kenney, C.; Phibbs, S. A Māori love story: Community-led disaster management in response to the Ōtautahi (Christchurch) earthquakes as a framework for action. Int. J. Disaster Risk Reduct. 2015, 14, 46-55. [CrossRef]

48. Stevenson, J.; Kay, E.; Bowie, C.; Ivory, V.; Vargo, J. The data challenges of monitoring resilience. In Proceedings of the ISCRAM Asia Pacific 2018, Wellington, New Zealand, 5-7 November 2018.

49. Kwok, A.; Paton, D.; Becker, J.; Hudson-Doyle, E.; Johnston, D. A bottom-up approach to developing a neighbourhood-based resilience measurement framework. Disaster Prev. Manag. Int. J. 2018, 27, 255-270. [CrossRef]

50. Dando, K. Porirua Flooding Was ‘Unstoppable'. Dominion Post. 2015. Available online: https://www.stuff.co.nz/dominionpost/news/68891163/porirua-flooding-was-unstoppable (accessed on 2 December 2020).

51. Wong, S.; Macdonald, L.; Jolliff, E. Flooding Shuts Schools in Porirua. Newshub. 2016. Available online: https://www.newshub. co.nz/home/new-zealand/2016/05/flooding-shuts-schools-in-porirua.html (accessed on 2 December 2020).

52. Mason, K.; Lindberg, K.; Read, D.; Borman, B. The importance of using public health impact criteria to develop Environmental Health Indicators: The example of the indoor environment in New Zealand. Int. J. Environ. Res. Public Health 2018, 15, 1786. [CrossRef]

53. Briggs, D.J. Making a Difference: Indicators to Improve Children's Environmental Health; World Health Organization: Geneva, Switzerland, 2003.

54. Advisory Committee on Official Statistics. Good Practice Guidelines for the Development and Reporting of Indicators; Statistics New Zealand: Wellington, New Zealand, 2009.

55. Wisner, B.; Gaillard, J.; Kelman, I. Framing disaster: Theories and stories seeking to understand hazards, vulnerability and risk. In Handbook of Hazards and Disaster Risk Reduction; Wisner, B., Gaillard, J., Kelman, I., Eds.; Routledge: London, UK, 2012. 
56. Faustini, A.; Martuzzi, M.; Mitis, F.; Forastiere, F. Susceptibility and Integrated Assessment of Health Risks. In INTARESE Work Package 1.5: Cross-cutting issues in Risk Assessment. 2010. Available online: http:/ /www.integrated-assessment.eu/eu/index5 5c3.html?q=content/susceptibile_groups (accessed on 4 October 2019).

57. Durie, M. A Māori perspective of health. Soc. Sci. Med. 1985, 20, 483-486. [CrossRef]

58. Commonwealth of Australia. National Strategic Framework for Aboriginal and Torres Strait Islander Peoples' Mental Health and Social and Emotional Wellbeing; Department of the Prime Minister and Cabinet: Canberra, Australia, 2017.

59. Richmond, C.; Ross, N.; Bernier, J. Exploring Indigenous Concepts of Health: The Dimensions of Metis and Inuit Health; Aboriginal Policy Research Consortium International; Thompson Educational Publishing: Toronto, Ontario, 2007; Volume 115.

60. WHO. Constitution; World Health Organization: Geneva, Switzerland, 1948.

61. Blake, D.; Marlowe, J.; Johnston, D. Get prepared: Discourse for the privileged? Int. J. Disaster Risk Reduct. 2017, 25, 283-288. [CrossRef]

62. Phibbs, S.; Kenney, C.; Severinsen, C.; Mitchell, J.; Hughes, R. Synergising public health concepts with the Sendai Framework for Disaster Risk Reduction: A conceptual glossary. Int. J. Environ. Res. Public Health 2016, 13, 1241. [CrossRef]

63. Atkinson, J.; Salmond, C.; Crampton, P. NZDep2013 Index of Deprivation; University of Otago: Dunedin, New Zealand, 2014.

64. Statistics New Zealand. How Prepared Are New Zealanders for a Natural Disaster? Statistics New Zealand: Wellington, New Zealand, 2012.

65. Ministry of Health. Household Food Insecurity Among Children in New Zealand; Ministry of Health: Wellington, New Zealand, 2019.

66. Beban, J.; Gunnell, S. Incorporating Social Vulnerability into Land Use Planning and Local Government Processes for Management Natural Hazards and Climate Change in New Zealand; Urban Edge Planning Ltd.: Wellington, New Zealand, 2019.

67. Aitsi-Selmi, A.; Murray, V. Protecting the health and well-being of populations from disasters: Health and health care in The Sendai Framework for Disaster Risk Reduction 2015-2030. Prehosp. Disaster Med. 2015, 31, 74-78. [CrossRef] [PubMed]

68. O'Sullivan, T.; Bourgoin, M. Vulnerability in an Influenza Pandemic: Looking beyond Medical Risk; Public Health Agency of Canada: Ottawa, ON, Canada, 2010.

69. Ministry of Health. New Zealand Influenza Pandemic Plan: A Framework for Action, 2nd ed.; Ministry of Health: Wellington, New Zealand, 2017.

70. Amore, K. Severe Housing Deprivation in Aotearoa/New Zealand: 2001-2013; He Kainga Oranga/Housing \& Health Research Programme; University of Otago: Wellington, New Zealand, 2016. 